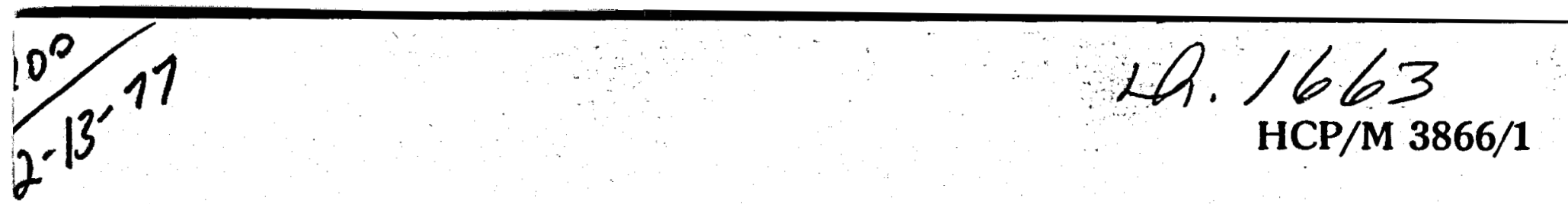

\title{
Financial Incentives Research and Lending Market Impact Analysis
}

Publication Date: November 1977

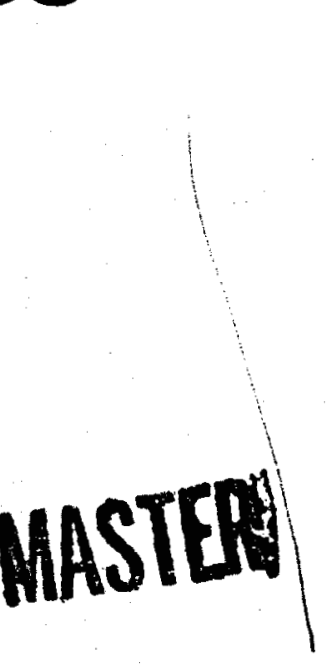

Bradford National Corporation

\author{
Prepared for \\ U.S. Department of Energy \\ Under Contract No. EX-76-10-C-3866
}

Division of Transportation Energy Conservation

Division of Building and Community Systems

Division of Geothermal Energy 


\section{DISCLAIMER}

This report was prepared as an account of work sponsored by an agency of the United States Government. Neither the United States Government nor any agency Thereof, nor any of their employees, makes any warranty, express or implied, or assumes any legal liability or responsibility for the accuracy, completeness, or usefulness of any information, apparatus, product, or process disclosed, or represents that its use would not infringe privately owned rights. Reference herein to any specific commercial product, process, or service by trade name, trademark, manufacturer, or otherwise does not necessarily constitute or imply its endorsement, recommendation, or favoring by the United States Government or any agency thereof. The views and opinions of authors expressed herein do not necessarily state or reflect those of the United States Government or any agency thereof. 


\section{DISCLAIMER}

Portions of this document may be illegible in electronic image products. Images are produced from the best available original document. 


\section{NOTICE}

This report was prepared as an account of work sponsored by the United States Government. NeIther the United States nor the United States Department of Energy, nor any of their employees, nor any of their contractors, subcontractors, or their employees, makes any warranty, express or implied, or assumes any legal liability or responsibility for the accuracy, completeness or usefulness of any information, apparatus, product or process disclosed, or represents that its use would not infringe privately owned rights.

Available from:

National Technical Information Service (NTIS)

U.S. Department of Commerce

5285 Port Royal Road

Springfield, Virginia 22161

Price: Printed copy: $\$ 6.00$

Microfiche: $\$ 3.00$ 


\section{Financial Incentives \\ Research and \\ Lending Market Impact Analysis}

Russell F. Smith

Patricia S. Bryant

Edward E. Cour

Paul C. Kouchoukos

By

Bradford National Corportation

\# 2 Research Place

Rockville, Maryland 20850

Under

Contract No. EX-76-10-C-3866

This report wa prepured \&s an eccount of work

sponsored by the United States Govemment. Neither the

United States nor the United States Department of

Enerd, nor any of their employees, aor any of their

contractors, mubcontractors, or their employees, makes

any warrinty, express or inplied, or asumes any logal

liability or responsibility for the sccuracy, completeness

of usefuliness of any information, apperatus, product or

process disclosed, or sepresents that tha use wowld not

infringe privately owned rights.

\section{Publication Date \\ November 1977}

Prepared for

U.S. Department of Energy

Washington, D.C. 20545

Division of Transportation Energy Conservation

Division of Building and Community Systems

Division of Geothermal Energy 
Table of Contents

List of Figures

iii

Executive Summary

iv

1 Introduction

I.I General

1.2 Energy' Legislation

1.3 Overview of ERDA Loan Guaranty Programs

1.4 Basis for the Investigation

1.5 Purpose of the Study

1.6 Scope

2

Background

2.1 General

2.2 Markets in General

2.3 Financial Markets

2.4 Capital Markets

2.5 Financial Intermediories

2.6 Financial Institutions

2.7 Business Term Loans

3 Methodology

3.1 General

3.2 Approach

3.3 Sources of Debt Capital

4 Data Collection and Analysis

4-1

4.1 General

4.2 Characteristics of the ERDA Programs

4.3 Financial Community Interest

4.4 Discussion Topics

4.4.1 Full Faith and Credit

4.4.2 Loan Guaranty. Withdrawal

4.4.3 Payment Upon Default

4.4.4 Default and Liquidation

4.4.5 Loan Servicing

4.4.6 Secondary Market Considerations

4.4.7 Interest Rates

4.4.8 User Charge

4.4.9 Interest Assistance

4.4.10 Cost Overruns and Cost Escalations

4.4.11 Default Experience

4.4.12 Probable Program Participation

4.4.13 Decision and Approval Authority

4.4.14 Program Control 


\section{TABLE OF CONTENTS (Continued)}

4.5 Summary of Principal Points and Recommendations 4.6 General Conclusions

Appendix A Discussion Participants

Appendix B Points of Contact

B-1

Appendix C Demand Deposits by City

C-1

Appendix D Gross Funds Supplied, by Type of Lender

D-1

Appendix $E$ Summary of Principal Points and Recommendations
by Specific Loan Guaranty Program.

Appendix F Bibliography 


\section{LIST OF FIGURES}

Figure

Page

3-1 Methodology Employed

3-3

3-2 Summary of Flow of Funds Accounts for the Year 1975

3-3 Institutional Types and Their Interest in ERDA's Loan Guaranty Programs

3-4 Regional Segregation of Financial Community

3-5 Finance/Commerce Regions

$3-11$

3-6 Demand Deposit Distribution by Region

3-7 Regional Distribution of 300 Largest

Banks in U. S. 



\section{EXECUTIVE SUMMARY}

The U. S. Energy Research and Development Administration (ERDA) has been authorized through recent legislation to design, develop, and implement several energy related loan guaranty programs. These programs are designed to encourage the private sector to participate in the development of alternative ehergy sources and the conservation of energy. To accomplish this goal, it appeared advisable to consult with potential private sector lenders in building the structure within which loan guaranty programs should operate. In a joint effort, the managers of the ERDA loan guaranty programs contracted for an independent financial incentives research investigation and lending market impact analysis. The purpose of this effort was to contact lending institutions to gain first hand knowledge of their attitudes toward the various existing and proposed ERDA loan guaranty programs. These institutions were queried as to how these particular loan guaranty programs should be altered or initially structured to minimize potential administrative problems and to facilitate the flow of continued credit to potential participants in the future. A long-term objective was to establish an interface and working dialogue with leaders of the financial community, which would facilitate early and rapid implementation of various energy related loan guaranty programs. This report details the results of that effort. The first two sections introduce ERDA loan guaranty programs and present an overview of various aspects of the financial community.

The third section deals with methodology. It addresses the methodology used in stratifying the financial lending sector and isolating the specific organizations selected for interview.

The general opproach utilized to develop the interview sample involved:

- Analyzing the known sources of available debt capital by institutional types.

- Selecting those institutional categories deemed most likely to participate in lending of the type envisioned under the ERDA programs. 
- Verification of institutional lending authority and interest through contact with various Federal regulatory/oversight agencies and major "trade associations" representing these lender categories.

- Stratification of these lender categories by regions and dollar value of transactions within regions.

- Identification of specific institutions by name within each category and geographic location which were the principal lenders in their respective fields.

- Direct interface with the selected candidates.

Six cities were selected to obtain a geographical representation of financial institutions across the country. Forty-one executive level representatives of financial institutions from six cities participated in the discussions. The cities selected represented approximately one-third ( $\$ 64$ billion) of all demand deposits in the Nation.

Section 4, Data Collection and Analysis, presents the results of the direct interface with the financial community. The information gathered in terms of basic philosophy, specific procedural matters, and technical concerns proved invaluable in the development of specific recommendations.

There was generally a mixed reaction from the financial community. Some members were genuinely interested while others were openly disinterested. Still others appeared to assume a "wait and see" attitude. Interest split along generic lines with brokerage houses expressing particular interest in secondary market considerations. They were keenly interested in seeing programs structured so as to allow dealing in the secondary market. On the other hand, commercial banks expressed interest in making primary loans and integrating them as part of their portfolios.

Generally the discussions dealt with specific segments of the various loan guaranty regulations. There were indications that the private sector considers the Government lacking in financial expertise and in the ability to respond to problems in a timely manner. They also were concerned with the meaning and interpretation of the regulations. Major topics of discussion were: 
- Full Faith and Credit

- Payment Upon Default

- Loan Servicing

- Interest Rates

- Interest Assistance

- Default Experience

- Decision and Approval Authority
- Loan Guaranty Withdrawal

- Default and Liquidation

- Secondary Market Considerations

- User Charges

- ... Cost Overruns/Cost Escalations

Probable Program Participation

Program Control

Several significant and important aspects of ERDA loan guaranty programs are discussed throughout this report. Those aspects which could have the most critical impact on ERDA programs are summarized below.*

\section{Full Faith and Credit}

- ERDA loan guaranty regulations and the Public Laws authorizing them should be modified and/or amended to include a definitive statement of "full faith and credit."

\section{Loan Guaranty Withdrawal}

The Geothermal Loan Guaranty Regulations should be amended to provide that "in any event, excluding fraud and misrepresentation, the lender shall be reimbursed for unpaid principal and accrued interest," for amounts previously disbursed by mutual consent of the lender and ERDA.

\section{Payment Upon Default}

- A specific fund should be established to support the Electric and Hybrid Vehicle loan guaranties and any future similar programs to assure potential lenders that funds will be available to make payment upon default.

- ERDA should seek revolving appropriations for funds to cover at least 20 percent of anticipated outstanding loan guaranties.

- ERDA should be empowered with authority to borrow, from the Treasury, funds necessary to discharge the Government obligation upon default in a timely manner.

- Interest rates for the period between date of default and date of payment should continue at the same rate as was in effect for the loan.

* Specific breakdowns by program are included in Appendix E. 


\section{Default and Liquidation}

- If provisions for technical default exist in the loan agreement, ERDA should be informed regularly of the status of the technical default indicators.

- Some flexibility should be allowed the lender in postponing the calling of default. This flexibility should be provided for in the regulations.

- ERDA loan guaranty regulations should be changed to define default as "nonpayment of principal, interest, or user charge (if the user charge is passed on to the borrower)."

Loan Servicing

- The current Geothermal Regulations and the regulations for future loan guaranty programs should be identical with the Electric and Hybrid Vehicle Regulations with respect to the area of guaranty withdrawal.

\section{Secondary Market Considerations}

- The possibility of divisibility should be considered by the ERDA Office of the General Counsel to determine the most reasonable approach. All sale and re-sale procedures of guarantied loans should be documented and standardized.

\section{Interest Rates}

- Floating interest rates should be considered as a viable option in loan guaranties.

User Charge

- A fixed rate for user charges should be explicitly stated in the regulations.

- The user charge should be paid at the time each disbursement is made.

Interest Assistance

- Existing and proposed loan guaranty regulations and the Public Laws authorizing them should be modified and/or amended to allow for interest and principal assistance.

\section{Cost Overruns and Cost Escalations}

- ERDA should establish contingency plans for additional financing for cost overrun/escalations at the beginning of each loan on a case by case basis. 
- Consideration should be given to requesting amendments to program laws to allow ERDA to exceed the current loan and/or program limits by some fixed percentage to allow contingency guaranties for project cost overrun/escalations.

Decision and Approval Authority

- Decision and approval authority, related to loan guaranties and subsequent related actions, should be delegated to the office of the appropriate Assistant Administrator. Such designation of authority should be stated in the regulations.

\section{Program Control}

- Positive program control should be vested in the program managers.

- Individual program managers should be given sufficient autonomy to directly interface with members of the financial community, borrowers and Governmental agencies.

- Designation of the program manager as a point of contact should be included in the regulations. 



\section{SECTION I}

\section{INTRODUCTION}

\subsection{General}

The U. S. Energy Research and Development Administration (ERDA) has been authorized by recent legislation to enter into loan guaranty and interest assistance agreements related to specific energy programs. These loan guaranty programs are designed to encourage the private sector to participate in the development of alternative energy sources and the conservation of energy. Two programs are currently authorized: one dealing with geothermal energy; the other dealing with electric and hybrid vehicles. A third program currently under consideration by the Congress addresses the conversion of organic waste products into alternative fuels.

Although each of the three loan guaranty programs identified above has distinct characteristics in terms of monetary limits, program life, potential borrowers, and technology applications, each will be under the Administrative control of ERDA and each will be generally competing within the same general financial markets. Accordingly, it will be in the best interests of both the Government and the lending sector to establish as much procedural and policy uniformity as possible among the three programs.

It should be noted that the Geothermal Loan Guaranty Program has been operative for approximately one year. As such, some sectors of the financial community have gained both experience and the opportunity to formulate specific opinions regarding the terms and conditions of both the authorizing legislation and implementing regulations. Prior to promulgation of firm implementation procedures for the Electric and Hybrid Vehicle Program or development of tentative plans for the pending additional programs it appeared advisable to contact the financial community to obtain their detailed views regarding the acceptability of both the current procedures and those proposed for the new programs. This report presents the results of such a 
financial community investigation. The results of this study, which was jointly sponsored by ERDA loan guaranty program managers, may not be necessarily applicable to all ERDA loan guaranty programs. There may be, however, certain topics of discussion that would be relevant for future loan guaranty or other financial incentives programs.

By way of an introductory overview, this section of the report provides a brief summary of:

- Energy legislation

- ERDA Loan Guaranty Programs

- Basis for the investigation

- Purpose of the investigation

- Scope of investigation

Subsequent sections of this report address related background information; methodology employed; data collection and analysis of the information obtained, and specific recommendations based upon the results of the analysis, Supporting information and reference data are included as appendices.

\subsection{Energy Legislation}

In an effort to reduce the current energy crisis, Congress has enacted a number of laws which authorize and direct implementation of specific energy related programs. Among these laws are the "Geothermal Energy Research, Development, and Demonstration Act of 1974," Public Law 93-410, and the "Electric and Hybrid Vehicle Research, Development, and Demonstration Act of 1976," Public Law 94-413.

Public Law $93-410$ provides (in part) for the:

- Research, development and demonstration (RD\&D) of geothermal energy technologies.

- Establishment of a loan guaranty program for the financing of geothermal energy projects.

Public Law 94-413 was enacted to authorize, within ERDA, a Federal program of research, development and demonstration designed to: 
- Promote electric vehicle technologies.

- Demonstrate the commercial feasibility of electric vehicles.

Additionally, Public Law 94-413 authorizes ERDA to establish a loan guaranty program to support Electric and Hybrid Vehicle RD\&D activities.

A third program relating to synthetic fuels from biomass* is currently being considered by the Congress. The Senate passed bill S-37 dealing with commercial biomass demonstration facilities on March 31, 1977. H. R. 6796, the ERDA appropriations bill, incorporates the provisions outlined in S-37. H. R. 6796 has been reported out by three committees and was placed on the calendar on June 21, 1977. As of the date of this report, the bill is still active but has not passed.

\subsection{Overview of ERDA Loan Guaranty Programs}

This paragraph provides an overview of ERDA loan guaranty programs which either have been or will be established in accordance with the Public Laws and bills discussed above. Common to each loan guaranty program is the goal of developing normal borrower-lender relationships which encourage the private flow of credit to assist the commercial development of each program without the need of continued Federal assistance. They are also designed to promote maximum participation by the private sector. While the foregoing are common goals of all programs, each program has its own peculiar characteristics.

\section{- Geothermal Loan Guaranty Program}

The objectives of this program are to:

1) Encourage and assist the public and private sectors to accelerate development of geothermal resources by enabling ERDA to minimize the ler,der's financial risk associated with the introduction of new geothermal resources and technology.

2) Develop normal borrower-lender relationships which encourage the flow of credit so as to assist in the development of geothermal resources without the need for Federal assistance.

*Biomass is matter which can be converted into synthetic fuels. This includes such material as animal and timber waste, urban and industrial waste, sewage sludge, and oceanic and terrestrial crops. 
Guaranties approved under this program, which was implemented on May 26, 1976, are limited to 75 percent of the eligible costs of a project. However, guaranties may cover 100 percent of a loan. Interest rates for loans are determined by the borrower and lender, and approved by the Administrator of ERDA in consultation with the Secretary of the Treasury. Loan guaranties are limited to a maximum of $\$ 25,000,000$ for any single project and to $\$ 50,000,000$ for any individual borrower. Maximum maturity for loans under this program is 30 years. There is no limitation in the basic law stating the total of all guaranties which may be outstanding. However, the amount of Federal liability which may be incurred under this program is established in separate legislation.* No guaranty may be approved after the period ending September 3, 1984 (10 years after the date of enactment of the Geothermal Energy Research, Development, and Demonstration Act of 1974, Public Law 93-410).

- Electric and Hybrid Vehicle Loan Guaranty Program

It is expected that this program will become operational within the next four months. The principal objectives of this program are to:

1) Encourage and assist the private sector to accelerate development of electric and hybrid vehicles for introduction into the Nation's transportation fleet.

2) Assure that qualified small business concerns and other qualified borrowers are not excluded from participation in such development by allowing ERDA to effectively reduce the lender's financial risk related to new electric and hybrid vehicle technology.

3) Develop normal borrower-lender relationships which will allow the flow of credit so as to assist in the continued development and production of electric and hybrid vehicles without the need for Federal guaranties.

Guaranties under this program are limited to 90 percent of the aggregate net cost of the project. Again, guaranties may cover up to 100 percent of a

*FY 1977 liability has been established as $\$ 200$ million. A request has been submitted to the Congress for an additional \$200 million. 
loan. Interest rates are defermined by the borrower and lender, and approved by the Administrator of ERDA. Loans are limited to a maximum of $\$ 3,000,000$ per project and $\$ 6,000,000$ per individual borrower. Maturity can be no greater than 15 years. Unlike the geothermal program, the Electric and Hybrid Vehicle Research, Development, and Demonstration Act of 1976, Public Law 94-413, establishes a limit of $\$ 60,000,000$ on the total of all outstanding guaranties or commitments to guaranty. Under the provisions of this program, no guaranty can be awarded after September 17, 198 I (a five-year period from the date of enactment of Public Law 94-413).

1.4 Basis for the Investigation

The only loan guaranty program which is fully operational is the Geothermal Loan Guaranty Program. Specific concerns on the part of the financial community have come to ERDA's attention regarding the following provisions of the program:

- $\quad$ Full faith and credit

- Specific date of payment in default

- Definition of default

- Loan servicing

- Principal and interest assistance

Based on discussions with members of the financial community during the course of this study, it is apparent that additional provisions related to all programs will require clarification. These include:

- Loan guaranty withdrawal

- Secondary market considerations

- User charges

- Cost overruns/cost escalations

Each of these areas is discussed in detail in Section 4. 
The purpose of this effort was to contact lending institutions to gain first hand knowledge of their attitudes toward the various existing and proposed ERDA loan guaranty programs. These institutions were queried as to how these particular loan guaranty programs should be altered or initially structured to minimize potential administrative problems and to facilitate the flow of continued credit to potential participants in the future. A long-term objective was to establish an interface and working dialogue with leaders of the financial community, which would facilitate early and rapid implementation of various energy related loan guaranty programs.

\section{$1.6 \quad \underline{\text { Scope }}$}

Based upon a preliminary analysis of the entire financial community, an isolation was made of those financial markets which would most likely participate as lenders in ERDA's loan guaranty programs. This potential lending market was then stratified by geographic area and the major potential lenders were then identified within each geographic area. This report is based on data acquired through direct interface with these representative lenders throughout the United States, a variety of government sources, and members of the ERDA staff. 

SECTION 2

\section{BACKGROUND}

\section{MARKETS - INSTITUTIONS - TERM LOANS}

\section{1 $\quad$ General}

Before discussing the detailed findings of this investigation, it may be well to present a synoptic overview of the general composition of the financial community. This will include brief descriptions of markets in general, financial markets, capital markets, financial intermediaries and financial institutions. It will also discuss general aspects of business term loans.

\subsection{Markets in General}

A market is any place where willing buyers and sellers meet to determine, through arms length transactions, a price for the exchange of goods or services. The characteristics of markets vary greatly. Some markets are national, some are local; some markets have characteristics that lead to price stability, some do not.

The price agreed upon by buyers and sellers-mthe crucial point to most market transactions--performs an economic service of great significance. Market prices and market popularity guide production. By guiding production, market prices determine the use made of economic resources. The same holds true for financial markets.

\subsection{Financial Markets}

Financial markets are not unlike other markets. They are the transmission mechanisms between lenders-savers and borrowers-spenders. Through a wide variety of techniques, instruments, and institutions, financial markets mobilize the savings of millions and channel them into the hands of borrower-spenders who need more funds than they have on hand. The ultimate function of financial markets, both primary (newissue) and secondary markets, is to allocate resources efficiently between different kinds of investments. Savings flow to those who are willing to pay the highest prices 
(interest rates) and thus savers are able to earn the highest real returns on investments. Allocative efficiency is further enhanced by the existence of secondary financial markets which add to the number of available choices in the formulation of the level, composition, and timing of saving and investment. In general, greater choice means greater allocative efficiency.

In markets for goods and services, real assets (or services derived from real assets) are exchanged for money, and vice versa. In financial markets, the exchange is between financial assets (debt or equity securities) and money. Money is traded in both markets; it is the link between the real and financial sides of the economy. Moreover, since money itself is a financial asset, financial market transactions involve exchanges of financial assets, one of which is money.

\section{$2.4 \quad$ Capital Markets}

Generally, within the financial market, a distinction is drawn between the market for long-term securities (a year or longer in original maturity), called the "capital market," and the market for shorter-term issues, the "money market."

The capital markets employ a wide range of institutions that perform the functions necessary for effective market performance. By far the largest sector of the capital market, in terms of dollar volume of securities outstanding, is the stock market. About 70 percent of all the outstanding stocks are owned by individuals, without the benefit of financial intermediation; the rest are held by such institutional investors as pension funds, mutual funds, and insurance companies.

In the corporate bond market, life insurance companies are the main lenders (owning more than a third of the corporate bonds), followed by pension and retirement funds and households. State and local government bonds, on the other hand, are bought primarily for their tax exempt features. Commercial banks own half of this debt, followed by individuals, and property and casualty insurance companies.

U. S. Government securities are generally acquired by a wide variety of purchasers, including the Federal Reserve, commercial banks, individuals, and for- 
eigners. The same is true of the securities of various Government agencies (such as the Federal Home Loan Bank, the Federal National Mortgage Association, the Government National Mortgage Association, and the Federal Land Banks). Some of these are guaranteed, formally or informally, by the full faith and credit of the Federal Government.

\subsection{Financial Intermediaries}

Financial intermediaries are financial institutions such as commercial banks, savings banks, savings and loan associations, credit unions, pension funds, and insurance companies which act as middlemen, transferring funds from ultimate lenders to ultimate borrowers. A commonality of all financial intermediaries is that they acquire funds by issuing their own liabilities to the public which are then used to acquire securities for themselves. The flow of funds from lenders to borrowers is shown in the illustration below.

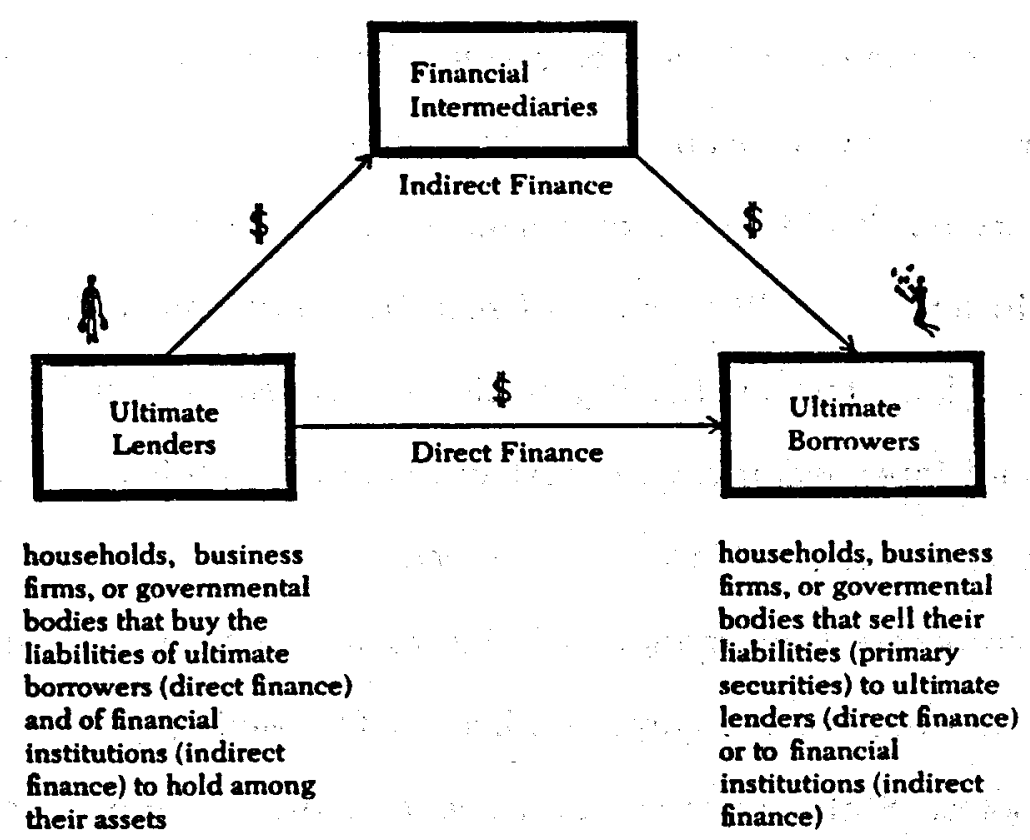

Financial intermediaries, whether they seek profit or not, must cover their costs of operation. The method for covering these costs is to borrow from savers at one rate of interest and then to lend to the ultimate investors at a higher rate of interest. 


\subsection{Financial Institutions}

Specialized institutions tend to have specialized policies for financial investment in the capital markets. Subject to legal, self-imposed, and practical constraints, financial investment policy. is determined by striking a balance between the two opposing forces of expected return on assets and the risk of asset loss. Financial institutions, like most lenders, seek high returns and low risk. The optimal allocation between various financial assets is a consideration of weighing risk versus return. Different institutions have different asset structures based upon their ability to tolerate varying degrees of risk and exposure. These differences are described in the paragraphs below.

- Commercial Banks

The customers of a commercial bank bring to it the funds it needs for its operations. This fact accounts for one principle that governs the employment of commercial bank funds--they must meet the basic service needs of customers to continue to enjoy their patronage. Another principle is that banks must be prepared to lend to good customers when the customers want loan accommodation.

Commercial banks have to be both liquid and profitable. Unfortunately, assets which are liquid reserves are not profitable, while those which are profitable (loans) are not liquid. The task of bank asset management is to strike a balance between the two.

Loans, like reserves, can assume different forms. At one time, short-term business loans were the dominant use of bank funds. These loans continue to occupy a special place in banking, but this type of credit fails to exhaust available funds in most banks; most are extended into wider lending activities. One extension takes the form of greater maturity. Business "term loans," a form of intermediate maturity credit, accommodate businesses in a way not available through short-term credit.

\section{- Mutual Savings Banks}

Mutual savings banks are much more specialized than commercial banks. Their original purpose was to encourage thrift among working-class people; that is, to provide an easy and safe way for the "average" person to save. The savings banks, in turn, were to invest these savings in the capital markets in such a way as to guarantee security of principal and interest. 
Savings banks experimented with several forms of financial investment, but they have settled on mortgages as their primary investment medium. Mortgages now constitute 75 percent or more of savings bank assets.

Recently, mutual savings banks have shown some interest in corporate equities as some states have liberalized regulations limiting stock acquisitions. The proportion of assets in corporate stocks, however, is still very small (below 5 percent).

\section{Savings and Loan Associations}

Savings and loan associations were originally introduced for the purpose of making mortgage credit available to persons who sought home ownership but who lacked access to banks and other sources of credit. Today there is little functional difference between savings and loan associations and mutual savings banks. Both these institutions secure funds by issuing savings accounts and both use funds by acquiring mortgages.

The investment policies of savings and loan associations are simple. They maintain required liquidity reserves and use all remaining funds to acquire mortgages. Liquidity is supplied by intermediate-term and longer-term U. S. Government securities:

\section{- Life Insurance Companies}

The primary mission of life insurance companies is to sell protection. The element of saving and investment associated with life insurance is incidental to this primary mission. Life insurance policies give their holders cash surrender values that equal or approach the holders' equity share of policy reserves. Since policyholder equity is stable, predictable, and slow to turn over, liquidity needs for life insurance companies are modest. Most investment is in long-term assets and the need to safeguard principal restrains life insurance companies from investing in high-risk, high-return securities.

Mortgages and long-term loans to businesses constitute about 80 percent of life insurance company assets. At one time, life insurance companies were important buyers of corporate bonds in the open markets, and small life insurance companies still make such purchases. However, the companies learned to make direct placement loans and found they could get better rates in this manner.

- Fire and Casualty Insurance Companies

Fire and casualty insurance companies are not typical financial institutions. This business requires reserves even more than 
does the life insurance business, since casualty underwriting risks are less subject to forecast than life risks. These reserves are not exactly in the equity province of either stockholders or policyholders, but funds do accrue and they require investment. The assets of fire and casualty insurance companies consist mainly of tax-exempt bonds and corporate stocks.

\section{Private Pension Funds}

The growth of private pension funds has been one of the striking financial developments of recent years. Pension plans were not at all common before World War II. Since then almost all companies have established such plans. In the attraction and retention of able officers and employees, they have become a virtual necessity. Tax exemption has also stimulated the growth of these funds. Employer contributions to the funds, as well as income earned on the funds, are exempt from the federal income tax.

Private pension funds have invested heavily in corporate stocks and to a lesser extent in corporate bonds. Equities are used for price level protection and bonds for their regularity of income.

So far there has been very little specific legal regulation except as the common law of trusteeship applies to them. Trustees of pension funds have a wide investment latitude.

\section{Government Pension Funds}

Unlike the private pension funds, public pension systems have been subject to detailed regulations and rules for investment. Public pension plans tend to require somewhat larger relative contributions from employees and relatively less from the employing governments. Even so, the larger part of the burden is still on the employing governmental units.

In the past, pension funds of state and local governments were often limited to investment in the securities of those bodies or in U. S. Government securities. However, pension funds of public authorities now are investing mainly in corporate bonds and stocks. All are bonds acquired in the public open market; direct placements are quite rare. Presently, state and local government pension funds are among the leading buyers of newly offered corporate bonds.

\section{- Mutual Fuńds}

Mutual funds secure savings by selling their own stocks or shares to individuals, which in turn are used for acquiring corporate stocks. When an individual buys into a mutual fund, he is indirectly buying a portfolio of stocks of many business corporations. 


\subsection{Business Term Loans}

Commercial banks, insurance companies, and certain stock brokers and dealers have become suppliers of intermediate and long term credit. The principal medium used for extending such credit to business borrowers is the "term loan," which is defined by the Federal Reserve as a commercial and/or industrial loan with an original maturity of more than one year. The proceeds of term loans are often used for general corporate purposes and project financing, including, for example, working capital, the acquisition of land and buildings, and the purchase of equipment. Firms that can pay for fixed assets in a relatively short period of time, for example, may find term loans more advantageous than long-term bonds or equity capital. So that the firm does not have to face the possibility of repaying the total loan at one time, payments are made according to a schedule which is usually based on the firm's projected cash flow.

Commercial banks sometimes participate with insurance companies, pension. funds, and various government agencies in making term loans. Participation with insurance companies involves large, long-term loans, wherein the bank takes the shorter maturity amount (first five to seven years) and the insurance companies take the remainder. Because of their relatively slight need for liquidity and their preference for long-term lending, insurance companies can be expected to impose more severe prepayment penalties on the borrower than are normally imposed by commercial banks. 


\section{SECTION 3}

\section{METHODOLOGY}

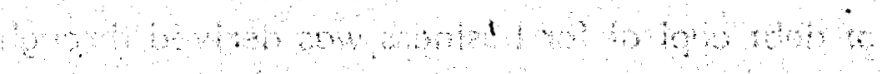

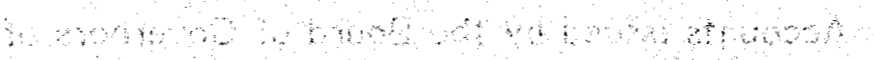




\section{SECTION 3}

\section{METHODOLOGY}

\subsection{General}

Because of the diversity and number of institutions involved in the financial community, it was necessary to develop a representative sample of those institutions most likely to participate in ERDA's Loan Guaranty Programs. This section addresses the methodology used in stratifying the financial lending sector and isolating the specific organizations selected for interview.

\subsection{Approach}

The general approach utilized to develop the interview sample involved:

- Analyzing the known sources of available debt capital by institutional types.

- Selecting those institutional categories deemed most likely to participate in lending of the type envisioned under the ERDA programs.

- Verification of institutional lending authority and interest through contact with various Federal regulatory/oversight agencies and major "trade associations" representing these lender categories.

- Stratification of these lender categories by regions and dollar value of transactions within regions.

- Identification of specific institutions by name within each category and geographic location which were the principal lenders in their respective fields.

- Direct interface with the selected candidates.

A graphic representation of this methodology appears in Figure 3-I.

\subsection{Sources of Debt Capital}

The determination of sources of debt capital for business was derived through examination of the latest Flow of Funds Accounts issued by the Board of Governors of the Federal Reserve System. This document indicated that of the nine categories of capital sources, the primary sources for business were provided by "commercial banks" 
Identify possible sources of debt capital by institution type

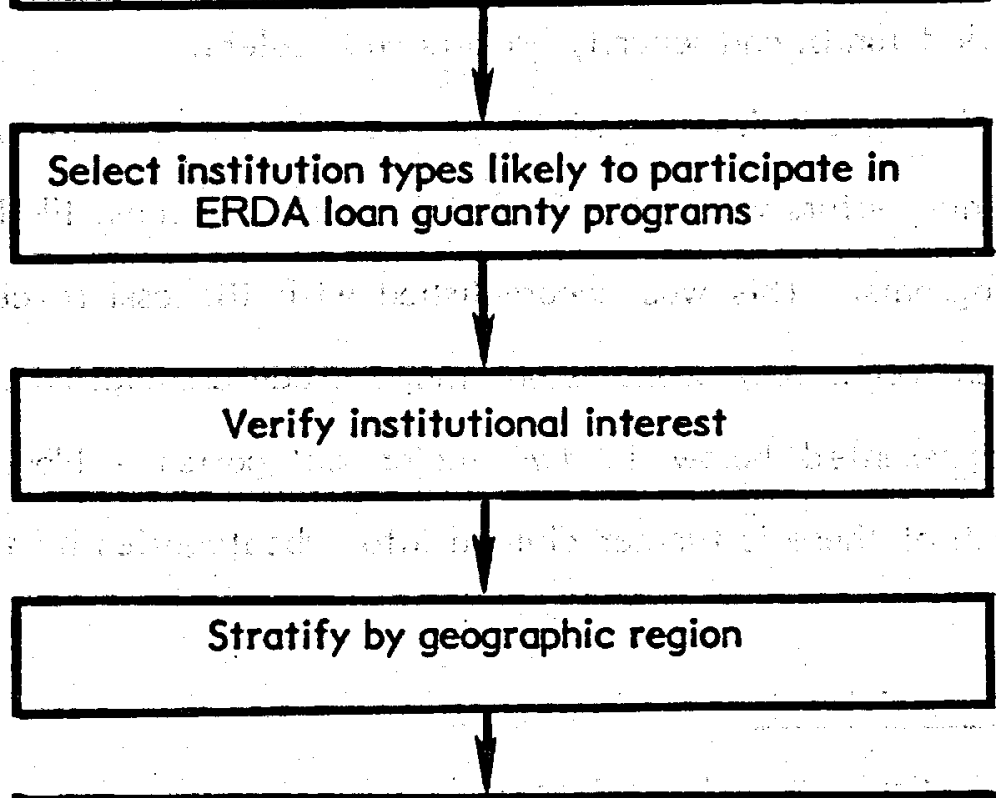

Stratify by transaction volume within region

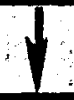

Identify largest lenders in each city

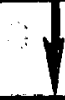

Hold discussions with selected candidates

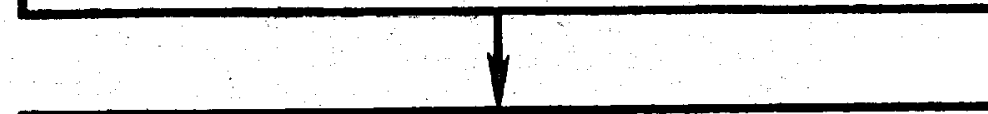

Synthesize and analyze discussions

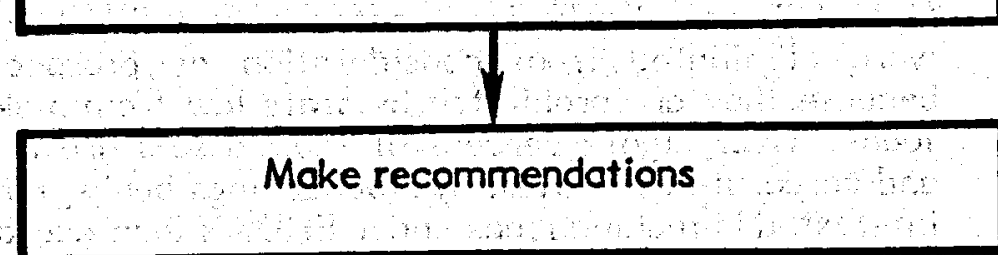

\section{METHODOLOGY EMPLOYED}

Figure 3-1 
and "private nonbank financial institutions." Refer to Figure 3-2. Private nonbank financial institutions include savings and loan associations, mutual savings banks, credit unions, life insurance companies, private pension plans, state and local government employee retirement funds, open-end investment companies, real estate investment trusts, money market funds, and security brokers and dealers.

In formulating our investigative approach, it was necessary to isolate the specific institutional sectors within the financial community most likely to participate in the ERDA programs. This was accomplished with the assistance and advice of various Government regulatory agencies and major trade associations. The results of this effort are presented below in two major categories - Nonparticipants and Participants. Each of these is further divided into subcategories by type of financial institution.

\section{- Nonparticipants}

- Savings and Loan Associations

Since Federal and state laws limit savings and loan associations to investing the major portion of their portfolios in housing and related areas within specific geographical regions, this group was eliminated as prospective lenders. Savings and loan associations are further constrained by law from making loans for high technology projects. This was confirmed by the:

Federal Home Loan Bank Board

U. S. League of Savings Associations

National Savings and Loan League

- Mutual Savings Banks

Mutual Savings Banks are located in only 17 states. These banks were eliminated from consideration as prospective candidates because they are prohibited by state law from making commercial loans. Over eighty percent of their assets are in mortgage loans and corporate securities. Mutual savings banks, however, would be interested in making loans under ERDA's loan guaranty programs if the loans were made in the form of bond issues and then only if the bonds were on the state's legal list of approved securities. On a case by case basis, mutual savings banks sometimes make moderate 


\begin{tabular}{|c|c|c|c|c|c|c|c|c|c|c|c|c|c|c|}
\hline \multirow[b]{3}{*}{ 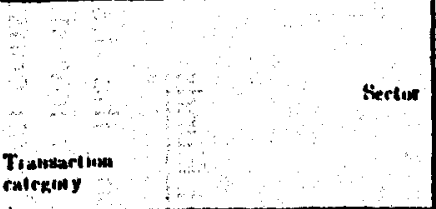 } & \multicolumn{4}{|c|}{ 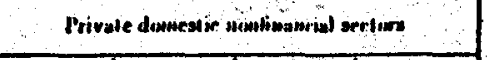 } & \multirow{2}{*}{ 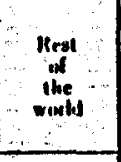 } & \multirow[b]{2}{*}{ anvi. } & \multicolumn{5}{|c|}{ Pinancial wectlows } & \multirow{2}{*}{ All } & \multirow{2}{*}{ Dimneter } & \multirow{3}{*}{ 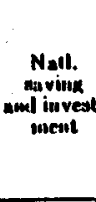 } \\
\hline & "lamser & $\begin{array}{l}\text { Iusi- } \\
\text { mess }\end{array}$ & 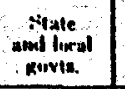 & Tinul & & & Tolal & 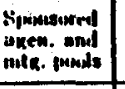 & $\begin{array}{c}\text { Nomev } \\
\text { Lary } \\
\text { nuthe } \\
\end{array}$ & Cinant & 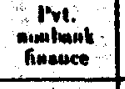 & & & \\
\hline & if 8 & 118 & a s 5 & 4 & II. s & 13 & 18 & $1 \mathrm{~s}$ & 0 is & II & o s & u. $s$ & v & \\
\hline 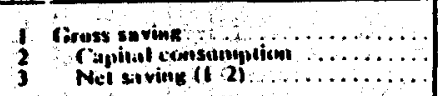 & $\begin{array}{l}\ldots . .258 .5 \\
19.6 \\
19.6 .8\end{array}$ & I3i! & & and & & … & \begin{tabular}{ll|}
$\cdots$ & 1.4 \\
$\cdots$ & 1.3
\end{tabular} & & & & & & & $\begin{array}{l}323.0 \\
2350 \\
177.9\end{array}$ \\
\hline 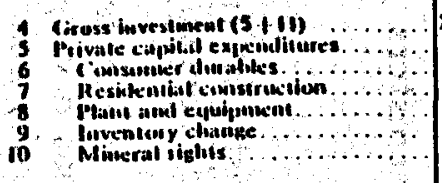 & $\begin{array}{l}20.9 \\
179.2 \\
131.7 \\
12.1 \\
\text { s.1 }\end{array}$ & $\begin{array}{l}122.8 \\
17.8 \\
193 \\
11.6 \\
1.3 .8\end{array}$ & 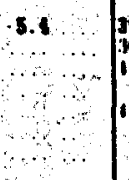 & 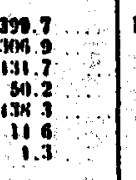 & $\begin{array}{cc}10.2 \ldots \\
\ldots \ldots \\
\ldots\end{array}$ & \begin{tabular}{cc|c|}
75.2 & \\
-1.3 & \\
\hdashline & \\
\hdashline$i .3$ & \\
\hdashline-3 & \\
\hdashline
\end{tabular} & $\begin{array}{ll}84 & \ldots \\
89 & \cdots \\
i g & \cdots\end{array}$ & .2 & .2 & 1.8 & i.j. & 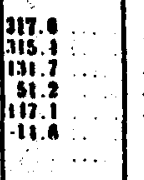 & iif & 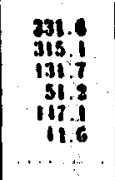 \\
\hline 11 Net Amancital investwem (12-13) & 1118. & 3.1 & 1.4 & n.e & $16.2 \ldots$ & 73.0 & .5 & 3 & 2 & 1.8 & 2.1 & 2.2 & 2.2 & 16.8 \\
\hline 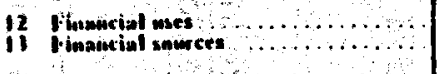 & $154.8 \mathrm{sj}$ & and it. & 10.4 is. $]^{2}$ & 203.1110 .8 & 15.1 oi. & 17.9 n. & in.e it.. & 15.8 & 11.2 & 3.. & ${ }^{110.2} \mathrm{ini.2}$ & ${ }^{200.7}=10$ & 2.2 & $\begin{array}{lll}71.2 \\
15.1\end{array}$ \\
\hline 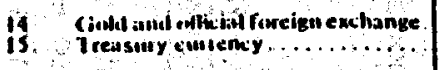 & & & & & & $\therefore \quad .0$ & $\therefore:$ & & $\therefore$ & & & 1.5 & - & \\
\hline $\begin{array}{l}16 \\
17 \\
17\end{array}$ & 8 & 2:3 & 3 & $\begin{array}{l}\text { in. } \\
\text { is. }\end{array}$ & i & $\begin{array}{lll}2.9 & 1 \\
2.9 & \cdots \\
2.9 & \end{array}$ & 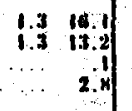 & $\because$ & $\begin{array}{r}11,2 \\
6 \\
0 \\
1.5\end{array}$ & & 1.2 & 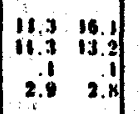 & $\begin{array}{l}0.8 \\
-.1\end{array}$ & \\
\hline $\begin{array}{l}\text { 2in } \\
21 \\
22\end{array}$ & $\begin{array}{l}11.1 . \\
39.7 \\
69.2 .2\end{array}$ & i: & $-2: 0$ & $\begin{array}{l}51.8 \\
25.7 \\
59.2\end{array}$ & & $1 \ldots$ & 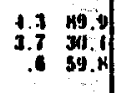 & & & & 3 & 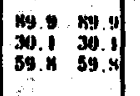 & & \\
\hline $\begin{array}{l}\text { 21 } \\
24 \\
25\end{array}$ & 38.1 & & & 9.6 & & & $-3,5 \begin{array}{c}32 \\
12\end{array}$ & & & & & 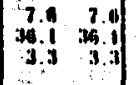 & & \\
\hline 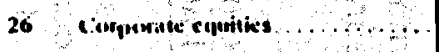 & $-1, x$ & & & 1.x $\quad y, y$ & $1.7 \quad 1$ & & B.7 $\quad 1.2$ & & & & 8.3 & 0.8 & & \\
\hline 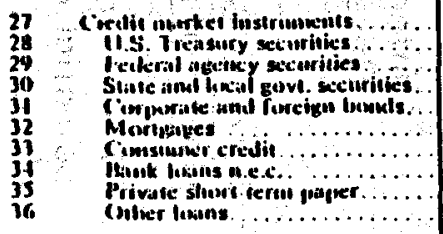 & 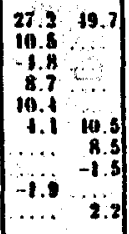 & 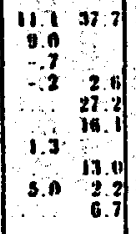 & $\begin{array}{ll}12.1 & 11.0 \\
2.7 & \\
17 & 11.7 \\
1.6 & \end{array}$ & 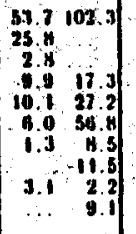 & 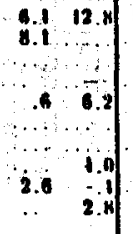 & 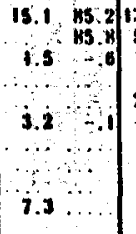 & 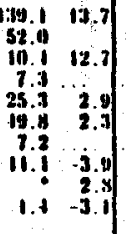 & \begin{tabular}{cc|}
14.5 & 03.8 \\
1.3 & 12.7 \\
15.7 &
\end{tabular} & $\begin{array}{ll}7.8 \\
7.0 \\
\cdots \\
\cdots \\
\cdots\end{array}$ & 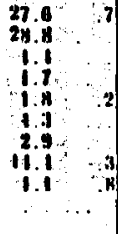 & 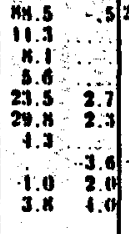 & 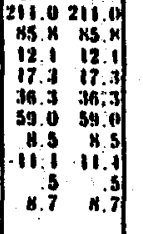 & $\ldots$ & \\
\hline 31 Secomity creatin. & $.1 \quad 2.2$ & $\ldots \ldots$ & & .22 .2 & 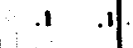 & $\cdots \cdots \cdots$ & $1.1 \quad 2.2$ & & & $1.9 \ldots$ & $\begin{array}{ll}2.5 & 2.2\end{array}$ & $\left|\begin{array}{ll}1.8 & 1.5\end{array}\right|$ & & \\
\hline 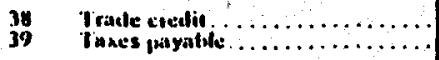 & & $\mid \begin{array}{cc}7.8 & 1.8 \\
\cdots \cdots & -2.2\end{array}$ & $\therefore \quad . .9 \mid$ & $\begin{array}{ccc}7.8 & 0.3 \\
-1 & -3.2\end{array}$ & $\begin{array}{lll}1.6 & 2.1 \\
\cdots & 2 & 2\end{array}$ & 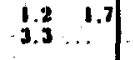 & $\therefore$ & & & & 8 & & $1 \cdot !$ & \\
\hline $\begin{array}{l}40 \\
41\end{array}$ & $-3.8 \cdots$, & 1i.3 $\quad 2.0 .1$ & .. & is.i 3.9 & is is. & $.7 \cdots$ & is.0 i2.0. & in. & 2 & $0.1: .8$ & i.o ii.t & 32.6 : 30.94 & -2.6 & . \\
\hline 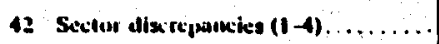 & -21.3 & 14.5. & 1.3 & 8.5 &. .3 & $.3 \ldots$ & $-8.6 \ldots$ & .3. & & -4.3 & $1.4 \ldots$ & .6 & n.6 & 3.7 \\
\hline
\end{tabular}

SUMMARY OF FLOW OF FUNDS ACCOUNTS FOR THE YEAR 1975 (Billions of dollars) 
purchases of tax-exempt securities depending on maturity, aftertax yields and liquidity of the securities. This information was confirmed by:

Federal Deposit Insurance Corporation

National Association of Mutual Savings Banks

- $\quad$ Credit Unions

Since the major purpose of credit unions is to serve their members, they make primary loans only to their members. Furthermore, the average credit union in this country has less than $\$ 2,000,000$ in total capital. Credit unions were therefore eliminated from further consideration. It should be noted, however, that under the provision of the Federal Credit Union Act, Public Law 95-22, credit unions may invest in Federally guarantied paper from the secondary market. Our sources of information were:

National Credit Union Administration

National Association of Federal Credit Unions

Credit Union National Association

- Corporate Pension Funds, State and Local Government Retirement Funds

The first three types of institutions discussed in this section were eliminated because of statutory constraints on the use of their funds. Unlike those institutions, pension funds and retirement funds were not considered because of self-imposed constraints. These funds prefer not to become primary lenders unless loans would enhance their members, (e.g.; job opportunity for members), or for firms or individuals known to fund managers. While these funds prefer not to become primary lenders, they may be interested in the direct purchase of bond issues and secondary market purchases of guarantied paper and bond issues. This was ascertained in discussions with the:

Department of Labor

Pension and Benefit Welfare Department

International Brotherhood of Teamsters

Research Group

- Finance Companies, Real Estate Investment Trusts, Open-end Investment Companies, and Money Market Funds

These types of institutions were eliminated from the list of potential candidates because each has a very specific investment objective. Finance companies generally concentrate on consumer 
credit and short-term commercial paper. Real estate investment trusts only make real estate investments. Open-end investment companies, commonly referred to as mutual funds, only purchase securities in the secondary market. Lastly, money market funds deal only in short-term Government securities and commercial paper. This information was confirmed by the following sources:

Securities and Exchange Commission Division of Investment Management.

Securities and Exchange Commission Division of Corporate Finance

Securities and Exchange Commisssion Division of Economic Research

Investment Company Institute

National Association of Real Estate Investment Trusts

With the elimination of these types of financial institutions, there remained commercial banks, security brokers and dealers, and insurance companies all of which have the ability and inclination to be primary lenders or to act as conduits into secondary markets.

\section{- Participants}

\section{- Commercial Banks}

Although commercial banks normally make loans of a shorter maturity, individual banks may be willing to make loans under ERDA sponsored Federal guarantied loan programs. However, it is the general consensus that only the largest banks would be so willing. The willingness of individual institutions to participate will be based on size and maturity of loans. This was confirmed by:

\section{Federal Reserve System}

Division of Research and Statistics

Comptroller of the Currency

Bank Organization and Structure

Federal Deposit Insurance Company.

Bank Division

American Bankers Association

Independent Bankers Association of America 


\section{- $\quad$ Security Brokers and Dealers}

While security brokers and dealers do not appear as obvious primary lenders, recent developments within this category warrant close examination. Within the past eighteen months, several large brokerage houses have established departments which may make and service primary loans backed by Federal guaranties. This was done primarily for the purpose of moving the guarantied paper into the secondary market. Other brokerage firms, on a regional basis, have established procedures to serve as syndicators of primary capital and to act as conduits into secondary markets.

Of particular note, when discussing security brokers and dealers in relation to guarantied loan programs, is a recent movement toward mutual effort. Although this movement is still in its infancy, interested security brokers formed an organization called the Public Securities Association. This organization covers all public financial areas. A second similar association, the Government Guaranteed Loan Association, is currently being formed. This association will specialize in SBA loans, Farmer's Home Administration (FmHA) loans, and other Federally guarantied loans. Our information sources in this area were:

Securities and Exchange Commission

Division of Market Regulation

The Securities Industry Association

National Association of Securities Dealers

Public Securities Association

Government Guaranteed Loan Association

- Insurance Companies

Insurance companies are primarily interested in direct placements of large loans and bond issues of long maturity with minimum risk. For these reasons, they would be interested, on a case-by-case basis, in making primary loans under each of the ERDA loan guaranty programs. Insurance companies would also be interested, to a lesser extent, in buying Federally guarantied paper in the secondary market. This information was confirmed by:

American Council of Life Insurance

State of Pennsylvania

Department of Insurance

A summary of the interests on the part of the financial community is shown in Figure 3-3.

Having isolated the categories of financial institutions which were most likely to participate, attention shifted to the choice of target financial/commerce centers by 


\begin{tabular}{|l|c|c|c|c|}
\hline & $\begin{array}{c}\text { Primary } \\
\text { Lenders }\end{array}$ & $\begin{array}{c}\text { Conduit to } \\
\text { Secondary } \\
\text { Market }\end{array}$ & $\begin{array}{c}\text { Secondary } \\
\text { Market } \\
\text { Purchasers }\end{array}$ & $\begin{array}{c}\text { No } \\
\text { Interesf }\end{array}$ \\
\hline Commercial Banks & $\times$ & & & \\
\hline Savings \& Loan Associations & & & & \\
\hline Mutual Savings Banks & & & & \\
\hline Credit Unions & & & & \\
\hline Life Insurance Companies & & & & \\
\hline Private Pension Funds & & & & \\
\hline State \& Local Government \\
Employee Retirement Funds & & & & \\
\hline Other Insurance Companies & & & & \\
\hline Finance Companies & & & & \\
\hline Real Estate Investment Trusts & & & & \\
\hline Open-end Investment Companies & & & & \\
\hline Money Market Funds & & & & \\
\hline Security Brokers and Dealers & & & & \\
\hline Individuals & & & & \\
\hline
\end{tabular}

INSTITUTIONAL TYPES AND THEIR

INTEREST IN ERDA'S LOAN GUARANTY PROGRAMS

Figure 3-3 
regions. It was considered advisable to do this so that possible regional differences could be accounted for. The approach taken was to divide the country into six (6) regions as shown in Figure 3-4.

\begin{tabular}{|c|l|l|}
\hline REGION & \multicolumn{1}{|c|}{ STATES } & CITY \\
\hline New England & $\begin{array}{l}\text { Maine, New Hampshire, Vermont, } \\
\text { Massachusetts, Connecticut, Rhode } \\
\text { Island }\end{array}$ & Boston \\
\hline Mid Atlantic & $\begin{array}{l}\text { New York, New Jersey, Pennsylvania, } \\
\text { Delaware, Maryland, Virginia, West } \\
\text { Virginia, District of Columbia }\end{array}$ & New York \\
\hline South East & $\begin{array}{l}\text { North Carolina, South Carolina, } \\
\text { Georgia, Florida, Alabama, } \\
\text { Mississippi, Tennessee }\end{array}$ & Atlanta \\
\hline North Central & $\begin{array}{l}\text { Michigan, Ohio, Indiana, Illinois, } \\
\text { Kentucky, Wisconsin, Minnesota, lowa, } \\
\text { North Dakota, South Dakota, Nebraska }\end{array}$ & Chicago \\
\hline South Central & $\begin{array}{l}\text { Texas, Oklahoma, Arkansas, Louisiana, } \\
\text { Kansas, Missouri }\end{array}$ & Houston \\
\hline West & $\begin{array}{l}\text { Montana, Wyoming, Colorado, New Mexico, } \\
\text { Idaho, Utah, Nevada, Arizona, Washington, } \\
\text { Oregon, California }\end{array}$ & San Francisco \\
\hline
\end{tabular}

Regional Segregation of Financial Community

Figure 3-4

After segregating the financial community by region, the next step was to isolate individual cities. See Figure 3-5. It was decided to select the city in each region which held the largest amount of demand deposit balances according to the latest statistics available from the Federal Reserve. (See Figure 3-6.) The cities selected represent approximately one-third of all demand deposits in the Nation. 
C

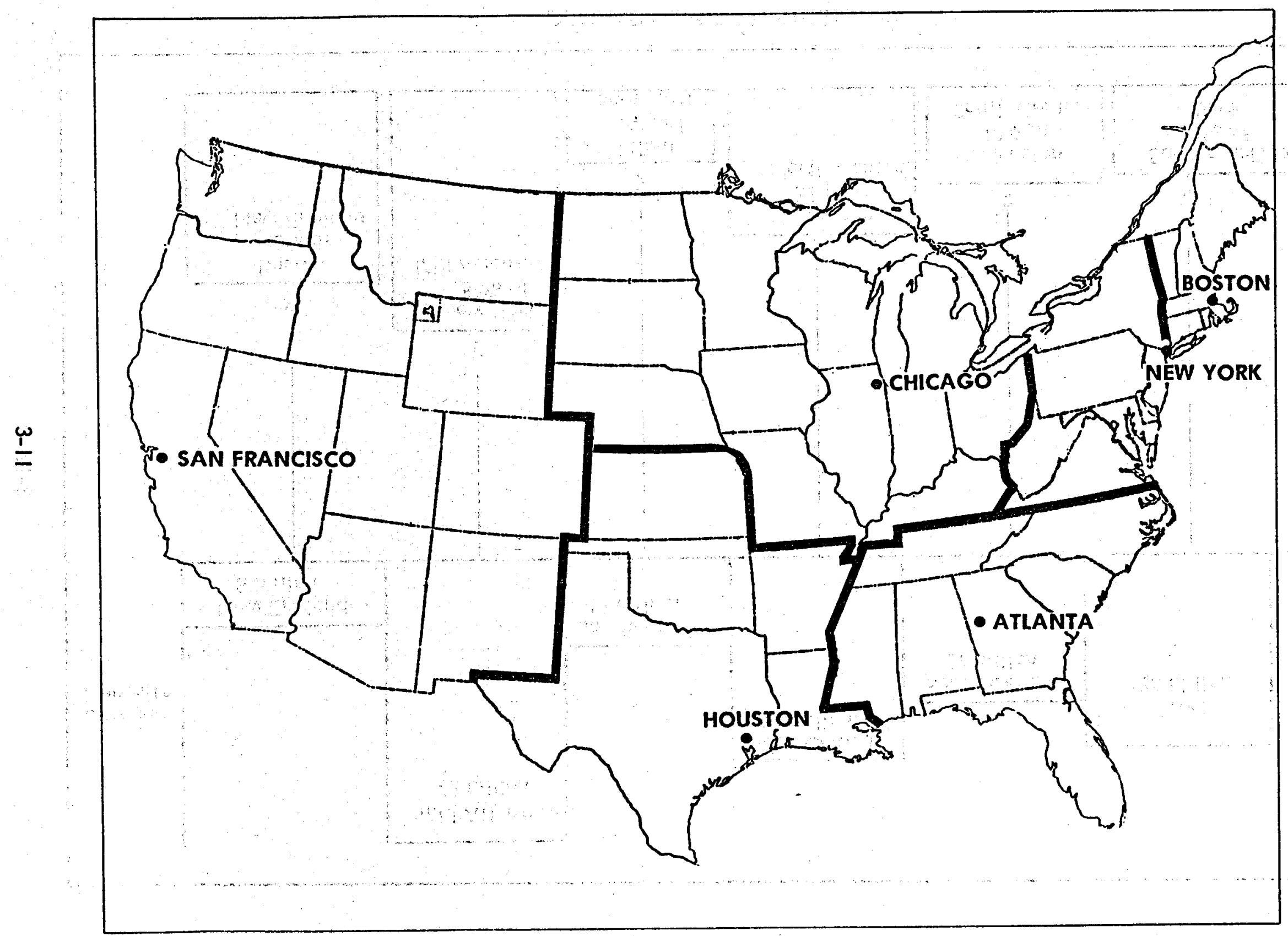

FINANCE/COMMERCE REGIONS

Figure 3-5 


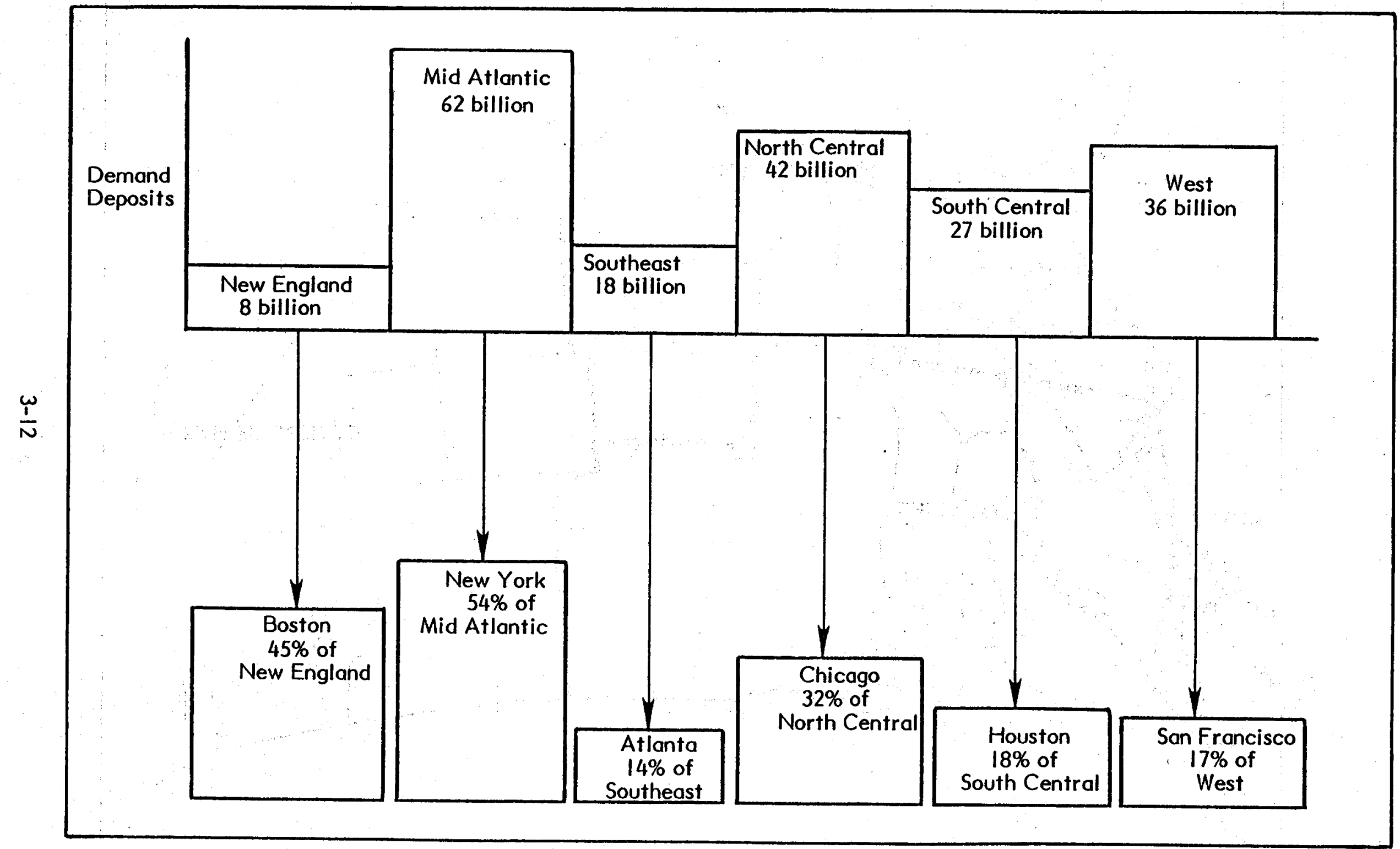

DEMAND DEPOSIT DISTRIBUTION

BY REGION AND BY CITY

Figure 3-6 


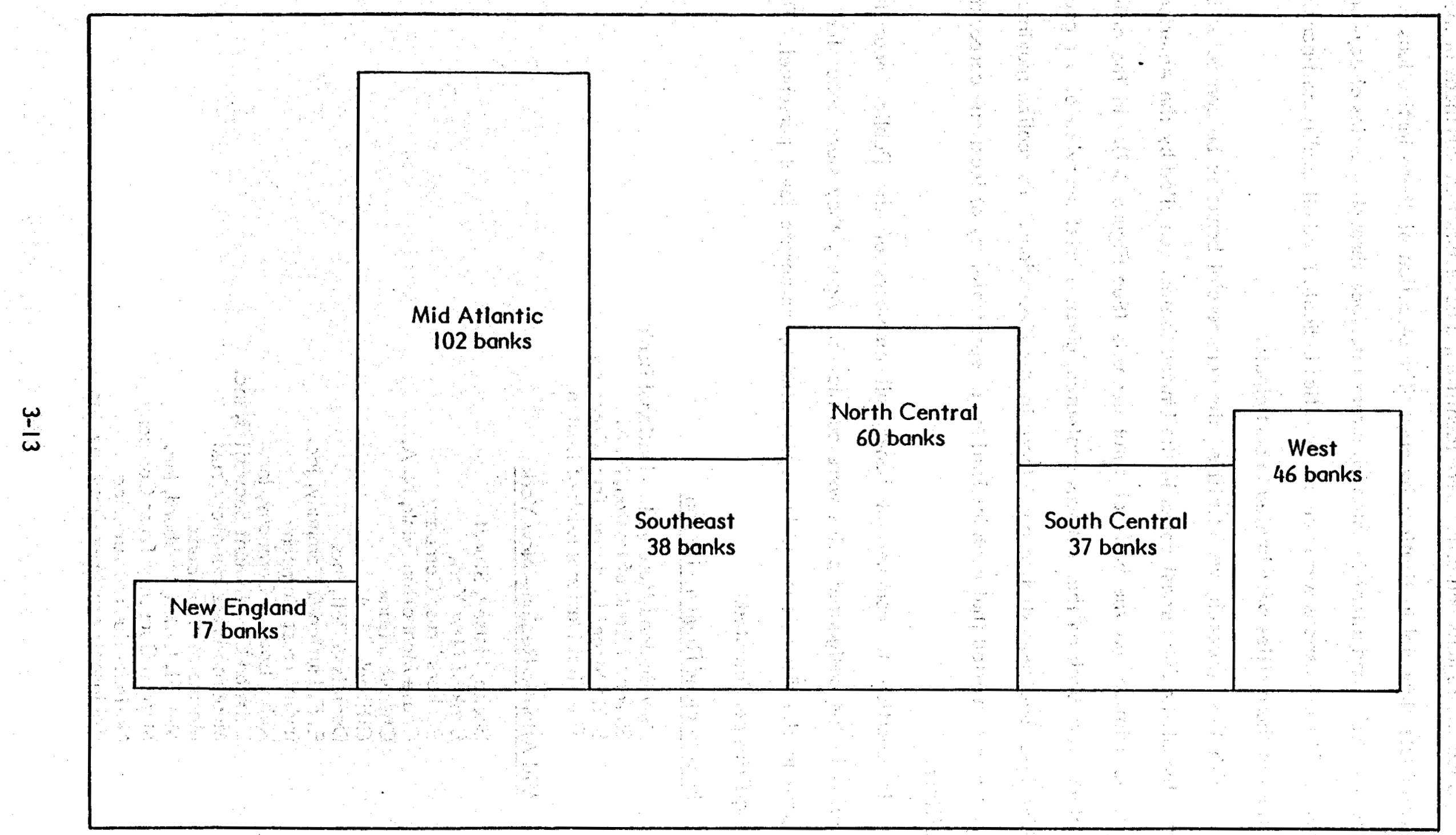

REGIONAL DISTRIBUTION OF 300 LARGEST BANKS INU. $s$.

Figure 3-7 
Once the regions and cities were identified, a determination was made of most likely candidate financial institutions by city. The selection of these institutions was based on the desire and intent to establish direct interface through a series of day-long discussions. The discussions were held in the cities indicated and all qualifying financial institutions in those cities were invited to participate.

With this approach, we identified the commercial banks to be contacted by using the list of the 300 largest banks in the United States, compiled by the American Banker's Association, on the basis of total deposits (See Figure 3-7). In the cities designated, every bank on that list was contacted, given a brief overview of our goals and objectives, and requested to participate in the discussions. To realize maximum benefit, it was requested that each institution be represented by at least one corporate level officer.

In addition to commercial banks, all members of the Public Securities Association in the designated cities were contacted. Again, they were requested to participate in the discussions and be represented by corporate level personnel. The following firms participated:

\section{New England Region - Boston}

New England Merchants - National Bank

Shawmut Bank of Boston, N. A.

State Street Bank and Trust Company.

The First National Bank of Boston

\section{Mid Atlantic Region - New York}

Bache, Halsey, Stuart

Bank of New York

Bankers Trust Company

Chase Manhattan Bank, N. A.

Chemical Bank

Citibank, N. A.

Daniels \& Bell, Inc.

E. F. Hutton \& Company, Inc.

Irving Trust Company

Kuhn, Loeb \& Company, Inc.

Lehman Government Securities, Inc.

Manufacturers Hanover Trust

Marine Midland Bank

Merrill, Lynch, Hubbard, Inc.

Morgan Guaranty Trust Company

National Bank of America

Robinson-Humphrey Company, Inc. 
South East Region - Atlanta

Citizens and Southern National Bank

First National Bank of Atlanta

Fulton National Bank of Atlanta

W. Dobbs and Company

Trust Company Bank

North Central Region - Chicago

Continental Illinois National Bank

First National Bank of Chicago

Northern Trust Bank

South Central Region - Houston

Bank of the Southwest

Business Finance Center of America, Inc.

Capital National Bank

First City National Bank

Hibbard, O'Connor \& Weeks, Inc.

Jesup \& Lamont, Inc.

West Region - San Francisco

Bank of America

California First Bank

Crocker National Bank 



\section{SECTION 4 \\ DATA COLLECTION AND ANALYSIS}

\subsection{General}

This section presents the results of the investigative team's direct discussions with the representative members of the financial community. Their comments in terms of basic philosophy, specific procedural matters and technical concerns proved invaluable in development of the recommendations which will be presented herein.

\subsection{Characteristics of the ERDA Programs}

ERDA programs differ from other major Federal loan guaranty programs in one extremely important aspect: the ERDA programs developed thus far are not envisioned to be ongoing for many years. Many other Federal loan guaranty programs such as $\mathrm{SBA}, \mathrm{FmHA}$, and FHA, have a continuing mission that requires making the same type loans (of relatively low value) over and over, year after year. Most major Federal loan guaranty programs are based on the following:

- The program is designed to continue indefinitely into the future.

- There is a high degree of repetitiveness in the type of transactions handled permitting standardization of processing procedures within the lending institutions.

ERDA's programs do not meet either of these characteristics. The technologies will vary widely; the amounts will be relatively large; the financial structure of most projects will be quite complex; and probably most importantly, there is little or no thought of on-going loan guaranty programs.

Further, other loan guaranty programs treat each individual loan as an independent process. Within ERDA loan guaranty programs there is significant likelihood of a synergistic relationship wherein several individual projects may be interdependent. In such a case, while one project is actually funded as an independent 
undertaking, its success or failure can affect the outcome of one or more related projects. Because of this possible interdependence, ERDA loan guaranty programs should be considered from a total program point of view.

One of the basic objectives of the ERDA programs is to provide the financial marketplace with some element of initial security while market members are being involved in new technologies. If ERDA guaranties a number of loans in different technological areas which together comprise a complete technological process, unsatisfactory results with loans for one phase of the process could create a financing void for that specific phase after termination of ERDA's statutory involvement. This could compromise the complete commercialization of a technology within the normal marketplace and would involve possible program jeopardy as a result of the financial community's lack of confidence in the technologies involved.

\subsection{Financial Community Interest}

The essential differences related to the ERDA loan guaranty programs (as discussed above) and the relative uniqueness of each loan to be guarantied, resulted in a mixed interest on the part of the study participants. Some interviewees were genuinely interested while others were openly disinterested. Still others appeared to assume a "wait and see" attitude.

During the discussions which ensued, interest split along generic lines. Brokerage houses expressed particular interest in secondary market considerations. They were keenly interested in seeing programs structured so as to allow trading in the secondary market. On the other hand, commercial banks expressed interest in making primary loans and integrating them as part of their portfolios.

Further, there were definite regional interests. Great interest in the Geothermal Program was found in the Western part of the country: Eastern and 
Midwestern interests were directed more toward Electric Vehicles. Subsequent to our discussions in the South Central Region, a new interest in the Geothermal Program was expressed. This interest coincided with recent increased efforts in the area of geopressure research and technology in Louisiana.

Generally, the discussions dealt with specific segments of the various loan guaranty regulations. There were indications that the private sector considers the Government lacking in financial expertise and the ability to respond to problem areas in a timely manner. The representatives expressed principle concern over the lack of assurance that the "full faith and credit" of the United States stood behind the loan guaranty agreement. They further expressed great concern over interpretations of various sections of the regulations which could result in the Government's withdrawal of the guaranty once the loan was consummated. The availability of funds and the timeliness of payment by the Government in the event of default were also major points of concern.

\subsection{Discussion Topics}

The major topics of discussion during each of the regional conferences included the following:

- Full Faith and Credit

- Payment Upon Default

- Loan Servicing

- Interest Rates

- Interest Assistance

- Default Experience

- Decision and Approval Authority
- Loan Guaranty Withdrawal

- Default and Liquidation

- Secondary Market Considerations

- User Charges

- Cost Overruns/Cost Escalations

- Probable Program Participation

Program Control 
Unless specifically noted these topics were found to be of uniform interest nationwide. Regional and program differences, where they exist, are highlighted. Each of these topics is discussed in the paragraphs which follow.

\subsubsection{Full Faith and Credit}

Because the "full faith and credit" of the United States is not specifically mentioned as backing ERDA's loan guaranties, the consensus of the participants was that this is a weak area in the regulations. Most felt that for these loan guaranty programs to be fully viable, some statement concerning "full faith and credit" should be included in the regulations. This is a minimum requirement. The preferred course of action would be to include such a statement in both the regulations and the Public Law authorizing each program.

- Discussion - The ERDA loan guaranty programs are new to the financial community and are the subject of close examination. The regulations and Public Laws which authorize these programs are being studied in great detail. The financial community feels it is imperative that "full faith and credit" be addressed specifically. The general consensus is that an implied "full faith and credit" is not completely acceptable. This is certainly the case from a psychological point of view as well as from the practical side.

- Recommendation - It is recommended that existing and proposed ERDA loan guaranty regulations, and the Public laws authorizing them, be modified and/or amended to include a definitive statement of "full faith and credit." To this end, an amendment to the Geothermal Energy Research, Development, and Demonstration Act of 1974, Public Law 93-410, has been passed by the House Science and Technology Committee which supports this recommendation by proposing to pledge the "full faith and credit" of the United States to the payment of guaranties. A similar amendment to the Electric and Hybrid Vehicle Research, Development, and Demonstration Act of 1976, Public Law 94-413, should be added. A definitive statement of "full faith and credit" should also be included in future loan guaranty legislation.

\subsubsection{Loan Guaranty Withdrawal}

There was considerable concern expressed on this subject. Many attendees noted that an honest oversight on the part of the lender in meeting servicing and 
reporting requirements could conceivably be construed as cause for withdrawal. Reference was made to the Geothermal Loan Guaranty Program, where the attendees maintain that the wording of the regulations gives the impression that withdrawal could occur for such reasons, leaving the lender exposed for any disbursed monies. This was not the case in the Electric and Hybrid Vehicle Loan Guaranty Program Regulations.
- Discussion - The financial community is concerned that strict interpretation of the Geothermal Loan Guaranty Program regulations can result in withdrawal even for the most innocent or unintentional errors. Section $790.36(\mathrm{c})$ of these regulations states, "If the lender fails to comply with any material term or condition set forth in the guaranty or loan agreement the guaranty may be terminated. Notice of the Manager's finding that a material term has not been complied with shall be served by the Manager upon the borrower, and the lender. Following notification, the borrower will be allowed reasonable time to acquire a substitute lender that is capable of complying with provisions in this regulation. If the borrower obtains a substitute lender satisfactory to the Administrator, a new guaranty agreement will be negotiated. Upon issuance of the new guaranty to the substitute lender, the original lender shall be reimbursed by the borrower for the unpaid principal outstanding and accrued interest." It is possible that such withdrawal could expose the lending institution to risk for the entire amount of funds disbursed. . While the financial com- munity accepts that such action is not intended by ERDA, the fact remains that it could occur. Such a possibility is perceived as a significant barrier to program participation by the financial community.

- Recommendation-It is recommended that the Geothermal Loan Guaranty regulations be amended to provide that "in any event, excluding fraud or misrepresentation, the lender shall be reimbursed for unpaid principal and accrued interest." The regulations for the Electric and Hybrid Vehicle Program already contain this provision and were generally accepted by the financial community. In developing regulations for the future loan guaranty programs, consideration should be given to incorporating a similar statement. It should be noted that this clause would apply only to those amounts which were previously disbursed by mutual consent of the lender and ERDA.

\subsubsection{Payment Upon Default}

This was a very popular topic of discussion in each region of the country.

Three major areas of discussion concern the date of payment upon default, the 
availability of funds to make payment, and the rate of interest in effect between date of default and date of payment. These are discussed below. A fourth area concerns the wording of the regulations. The financial community indicated that any wording which implies there may be complicated or uncertain political or administrative procedures involved in making payment in a timely manner, may impair the credibility of the guaranty in the market and dampen the interest of the financial community in these programs.

- Discussion - All Jenders, whether individuals or institutions, are interested in the repayment of loans made, particularly in cases where problems arise and default is possible. Of primary concern is the date on which repayment will be made. Lending institutions desire an unqualified, definitive statement of the date repayment will be made. As written, the regulations make payment within the specified time contingent upon the availability of funds. This is uncertain and not entirely acceptable to the financial community.

With regard to the availability of funds for payment in the event of default, the financial community requires assurance that funds will actually be available. "They suggest that a special fund be established for the express purpose of reimbursing lenders when default occurs. Without this ability, any statement of time or date of payment is suspect.

The third area of concern mentioned above relates to the rate of interest in effect between the date of default and the date of payment. The members of the financial community emphasized that the same rate which was in effeat for the loan should continue until repayment is made. This is particularly important for holders in due course who receive the obligation in the secondary market.

- Recommendation-It is recommended that specific funds be established to support the Electric and Hybrid Vehicle Loan Guaranties and any future similar programs. Such funds, established and identified at the Treasury, would act to assure and instill confidence in potential lenders regarding the support of Government in the Electric and Hybrid Vehicle Program and any future loan guaranty programs.

There is precedence for the establishment of such funds, both within ERDA and other Federal loan programs. Within ERDA, there is the Geothermal Resources Development Fund which has 
been authorized and funded. Similarly, within SBA, there is a Business Loan and Investment Fund created in the Small Business Act, Public Law 85-536, as amended (Sec. 4, (c) (I)). Both of the funds cited are revolving in nature.

Any similar Amendments establishing a fund for the Electric and Hybrid Vehicle Program and any future loan guaranty programs should be free of fiscal year limitations and provide specific identity for the default liquidation funds. These funds are derived from direct appropriations, user charges, and any proceeds of liquidations.

It is further recommended that ERDA seek revolving appropriations for funds to cover at least 20 percent of anticipated outstanding loan guaranties. There is no practical method of determining the amount of funds to be set aside for these new programs. To attempt to do so would require unieasonable investments of time and money. Lacking both, it is recommended that consideration be given to drawing on the experience of SBA. Even over the long period it has been involved with loan guaranties, the SBA still realizes a 15 percent default rate. With these new energy related programs and the high-risk, high-technology nature of each, an assumed default rate of 20 percent seems reasonable. In addition, it is recommended that such funds be appropriated on a revolving basis not subject to annual appropriation limitations. This would act to reassure the financial community.

A second recommendation is made to empower ERDA with authority to borrow from the Treasury funds necessary to discharge the Government obligation upon default in a fimely manner. This recommendation is supported by proposed amendments to the Geothermal Energy Research, Development, and Demonstration Act of 1974; Public Law 93-410, which would provide just such power to the Administrator. A measure of this type would also strengthen the "full faith and credit" posture of the guaranty.

Lastly, it is recommended that interest rates for the period between date of default and date of payment continue at the same rate as was in effect for the loan. Given that the previous recommendation empowering ERDA to borrow funds rapidly is accepted, the total dollar difference between face value of the loan and the short-term government rate would be relatively immaterial because of the short period of time between date of default and date of payment. This additional cost may be warranted by greater demand in primary and secondary markets. 


\subsubsection{Default and Liquidation}

In discussing default and liquidation a very real dichotomy appeared. Distinct and specific differences were obvious within the financial community when considering loans guarantied for 100 percent as opposed to those loans guarantied for less than 100 percent.

In the case of loans guarantied for 100 percent, with full faith and credit, and nonwithdrawal of the guaranty for funds already disbursed, the financial community was highly receptive to participating in these programs even with the other requirements to which they are not normally accustomed. Generally, for a 100 percent guaranty, they will accept the definition of default as "nonpayment of principal or interest." However, in the western part of the country certain financial instifutions preferred an expanded definition which recognized other technical bases for default.

If the lending institution is exposed to any risk at all, as in the case of a loan guaranty for less than 100 percent, they want to be in control of the default decision. This is based on the following assumptions on the part of the financial community:

- The financial institution is closer to the borrower.

- The financial institution will recognize problems earlier and is more qualified to assess them.

- The financial institution has more experience and expertise to react to potential default in a timely manner than the Government. In this regard, any undue delay can result in additional depreciation of assets and affect the value of collateral to the detriment of both the lender and the Government.

Therefore, the definition of default as "nonpayment of principal or interest," when applied to guaranties of less than 100 percent, is not acceptable and must be expanded.

An attempt was made to obtain a broader definition of default from the financial community. Our efforts were not totally successful as most members were 
hesitant to make definitive statements. However, technical default is generally considered in terms of the following provisions:

Working capital must be maintained above a specified minimum level.

Management must be acceptable to the lender. The borrower may be required to have "key-man" insurance on personnel in top level positions and the lender may reserve the right to approve hiring of new personnel.

The lender may place covenants in the loan agreement which prohibit or restrict the sale or pledge of assets, sale of receivables, making of loans, merger or consolidation, guaranteeing, endorsing or becoming a surety for others.

The loan agreements may restrict or limit salaries and bonuses, amount of dividends paid, total amount of borrowings, amount of funds which can be used to purchase plant equipment or to purchase the firm's capital stock.

Further limitations can be placed on the amount of long term debt which can be retired, without also retiring a portion of the debt held by the lender.

Misrepresentation of financial information presented in the loan statement may be grounds for default, as may be evidence of bankruptcy or insolvency.

While some institutions might accept a loan of less than 100 percent guaranty without such technical default provisions, the general impression derived during informal discussions is that the vast majority of lending institutions would not.

Regardless of the definition of default, the members of the financial community suggested that they would prefer some latitude or flexibility in calling default. Rather than being forced to call default when nonpayment occurs, the financial institutions would prefer to retain the option to work with the borrower in an attempt to preserve the loan but also reserve the option to call default at a later date. Since the provisions for technical default would give the institutions wider latitude in calling default, this option is more important in the case where default is defined simply as nonpayment of principal or interest. 
Liquidation is necessary in the case of default. Again, a dichotomy exists. Under a 100 percent guarantied loan, the financial institutions would prefer that liquidation be accomplished by the Federal Government. However, for loans guarantied at less than 100 percent, the financial institutions prefer to handle liquidation proceedings themselves. They are concerned that excessive delays would cause additional depreciation of assets and adversely affect the value of collateral. The lending institutions further feel that they should be paid a fee by the Federal Government for their services in processing liquidation for the Government's portion of the liquidation proceeds.

- Discussion-This particular point of contention seems to be moot. It is highly unlikely that lenders will make loans with less than a 100 percent guaranty. The provisions as written in the present regulations, which define default as simply nonpayment of principal or interest and delegate the responsibility for liquidation to the Attorney General, are acceptable to the financial community, with 100 percent guaranty, full faith and credit and nonwithdrawal of guaranty provisions. With these three conditions present, the lending institution has no risk at all. Literally, the lending institution has a risk-free loan in its portfolio. Since the Government is removing all risk of nonpayment for the lender, it can be reasonably assumed that ERDA should retain the right to define default to meet the needs of the program. Thus, no action should be taken, other than in association with our recommendation on "full faith and credit" and nonwithdrawal of guaranty. Since the possibility of awarding o guaranty of less than 100 percent of the loan seems small, we feel that should the situction arise, the problem be addressed on a case by case basis.

In addressing individual cases, certain points should be considered. With a guaranty of less than 100 percent, banks would want provisions for technical default in the loan agreement to protect the bank's (nonguarantied) portion of the loan. Although the nonguarantied portion may be small in relation to a total loan, the amount of the nonguarantied portion could represent a very significant investment. Of course, this is dependent on the size of the loan and the size of bank. For small and medium size banks, the investment would have greater importance than for large banks. Nevertheless, regardless of the size of the bank, risk will exist. For instance, 
assuming a guaranty of only 90 percent of a maximum loan, the lender would be responsible for $\$ 300,000$ under the Electric and Hybrid Vehicle Program and \$2.5 million under the Geothermal Program. With risks of this size, lending institutions would be compelled to protect their investment by including provisions for technical default into individual loan agreements. If the loan agreement does contain technical default provisions, it would be important for ERDA to be informed regularly of the status of the technical default indicators. This regular information flow would enable ERDA program management to retain program control; i.e., ERDA would be aware of possible technical default before the lender actually called it. This information flow would reduce the power of the lender to inadvertently disrupt the entire loan guaranty program.

When the financial status of a borrower becomes doubtful as to his ability to repay a loan, the lender would like to retain the option of working with the borrower to preserve the loan. This cooperation between borrower and lender could prevent default from occurring. However, the lenders prefer to have the option of calling default at a later time should all sources of loan preservation be exhausted.

At this point, it is noted that a totally new aspect of default arose. Independent of the discussions with the financial community, BRADFORD National Corporation personnel noted a possible problem area within the regulations as written. This problem centers around the user charge, which is paid by the lender but may be passed on to the borrower by the lender. A default definition limited to nonpayment of principal or interest leaves the door open for possible nonpayment on the part of the borrower of the user charge while continuing to pay the principal and interest payments. This places the lender in the position of being liable to ERDA for the user charge, unable to collect same from the borrower, unable to call default, and unable to cease making disbursements.

- Recommendation - If provisions for technical default exist in the loan agreement, it is recommended that ERDA be informed regularly of the status of the technical default indicators. This information flow should exist for all guaranties if ERDA is to retain program control.

It is recommended that some flexibility for calling default be provided in the regulations. In this case the lender retains control of the decision to exercise his demand for payment. This would allow the lender to work with the borrower to rectify problems of possible default. 
With regard to nonpayment of user charges, it is recommended that each ERDA loan guaranty regulation be changed to define default as "nonpayment of principal, interest or user charge (if the user charge is passed on to the borrower)."

\subsubsection{Loan Servicing}

In most regions of the Nation, lending institutions expressed reservations regarding reporting requirements in the loan servicing provisions of the regulations. These additional loan servicing requirements were construed as increasing the risk of guaranty withdrawal due to noncompliance with the lender-Government agreement. The financial community had great apprehension that simple errors of omission or commission could put the lender at risk by possible withdrawal of the guaranty. It was noted by the financial community that the additional servicing provisions, even though they appear simple on paper, are not within their normal policies and procedures. Concern was expressed that by their very nature, these loans would be handled on an "exception bașis" and, coupled with extraordinary servicing provisions, would increase the risk of honest error on the part of the lender.

A second point associated with the loan servicing sections of the regulations was the apparent inconsistency between "such care and diligence... as would be exercised by a prudent lender ..." and the definition of default as simple "nonpayment of principal or interest." The attendees pointed out that no prudent lender would make a term loan, 100 percent guarantied or not, without provisions for technical default.

- Discussion-It appeared that the financial community approached each program differently. Loan servicing requirements for the programs are the same. They are more acceptable in the Electric and Hybrid Vehicle Program than in the Geothermal Program. The Electric and Hybrid Vehicle Program has provisions for nonwithdrawal of the guaranty. The Geothermal Program has no such provision and guaranty withdrawal is possible. However, reservations exist regarding both programs. 
- Recommendations - It is recommended that the current Geothermal Regulations and the regulations for any future loan guaranty programs be identical, consistent with program objectives, to the Electric and Hybrid Vehicle Regulations, particularly in the area of guaranty withdrawal. This should reduce the apprehension about guaranty withdrawal which was evident within the financial community. It is realized that apprehension will still exist but no further recommendations are offered. ERDA must retain complete control of these programs. To this end servicing provisions such as these are necessary to assure this control. At the same time, it is recognized that these provisions do place additional burdens on the lender.

\subsubsection{Secondary Market Consideration}

While a few commercial banks showed some interest, primary interest in secondary market considerations was almost exclusively expressed by stock brokers and dealers. They felt that the timeliness of payment is of primary importance to a holder in due course as discussed in Payment Upon Default. They further suggested formalization of the documentation process to transfer the guaranty from the lender to the investor (holder in due course). Additionally, they felt that some specific provision regarding divisibility of loans should be included. Divisibility of loans (e.g., $\$ 100,000$ pieces) would allow easy assimilation and passage into secondary markets.

- Discussion - Because the secondary market consists of investors, with ordinary investor motivations, and not lenders, certain additional provisions should be included in loan guaranty procedures to attract the secondary market. The investor must be fully protected against all parties and all contingencies as to the par value of his commitment and interest thereon. If the borrower defaults, the investor must be promptly bought out without any delay due to liquidation or the necessity of demonstrating actual loss. The investor's guaranty must extend to the performance of the servicer (primary lender in most cases) so as to protect the investor should the servicer fail to pass payments through. The investor must be expressly designated as an innocent third party and must be protected should ERDA have cause for action against the lender which would lead to the removal of the guaranty. Guarantied portions of loans must be exempt from SEC registration to streamline entry into the secondary market. 
In addition to these points, there are three additional topics which are considered under this category; payment upon default, documentation process, and divisibility. The discussion and recommendations regarding default payments in paragraph 4.4.3 apply. It should be noted, however, that timely payment upon default is even more important to the secondary market. This is because the holder in due course is actually an investor, rather than a lender. The secondary market concern relating to the documentation process centers around the capability to show a clear transfer process from ERDA and the original lender to the eventual investor. This particular point is germane if ERDA decides it would like expansion of capital sources which might interface with their programs. This is considered a matter of internal ERDA policy and need not be regulated.

A third point of concern deals with the divisibility of loans. The secondary market is more receptive to paper in denominations smaller than those expected under the loan guaranty programs. It is felt that there must be some type of divisibility procedures to make possible the expansion of capital sources. For example, credit unions would not be able to hold a 2.5 million dollar instrument because, in most cases, that exceeds the size of their available funds. However, they would be able to hold instruments of $\$ 100,000$ denominations.

- Recommendation - The possibility of divisibility should be considered by the ERDA Office of the General Counsel to determine the most reasonable approach consistent with policy. In addition, all sale and re-sale procedures, as well as all associated documentation, must be standardized.

\subsubsection{Interest Rates}

The laws establishing ERDA's loan guaranty programs state that interest on guarantied loans by private lending institutions cannot be more than the rate prevailing in the private sector, and must be reasonable with respect to the project. Discussions in this area dealt with the type of interest rate, fixed or floating, which should be applied. The participants suggested that a need existed for flexibility within the regulations which allows for both fixed and floating interest rates. If this were done, the loan guaranty program could be adapted to any financial situation in both primary and secondary markets. Commercial banking institutions indicated a preference for a floating rate. The suggestion was made that a floating rate as a percent of the prime 
rate be considered for these programs. However, in dealing with the secondary market (i.e., brokerage houses), there is hesitation to accept floating rates. Some members of the secondary market would accept a floating rate only if they had no other recourse.

The question of the influence of loan servicing requirements on interest rates was also raised. The financial community felt that if the loan were 100 percent guarantied, backed by the "full faith and credit" of the U.S., and the guaranty could not be withdrawn (other than for fraud or misrepresentation), the servicing provisions would not result in a higher interest rate. Conversely, if these conditions did not exist, they felt that the increased risk of guaranty withdrawal for noncompliance with the servicing requirements would require additional internal administrative controls necessitating a higher interest rate.

Discussion - Interest rates depend on such important factors as the general level of interest rates, the amount and maturity of the loan, and the credit standing of the borrower. Rates on large loans are generally lower than on small loans because the costs of originating and administering a loan do not increase proportionately with an increase in loan size. The borrower's financial condition and profit prospects also have an important influence on the interest rate.

The rates on most small or short-term loans are fixed for the life of the loan. Large or long-term loans, on the other hand, often have a provision for a variable rate--that is, a rate that is adjusted upward or downward with changes in the prime bank rate. Long term loans have much more risk associated with the unknown future than short term loans. That is, as the maturity of the loans moves further into the future the market interest rates can be predicted with less certainty. Variable interest rates offer a hedge on the uncertainty of the behavior of future interest rates. Because of this hedge against uncertainty of the future a fair and reasonable interest rate for a variable rate loan may be less than a fair and reasonable interest rate for a fixed rate loan. For a long-term fixed rate loan, any prudent lender would be compelled to charge a rate high enough to protect him against the risk of any eventuality. Since longterm lending involves greater risk than does short-term lending because of the need for profitable operations over a relatively 
long period, financial institutions take added precautions when committing themselves to term loans. Economic conditions can change drastically from the time a loan is made until its final maturity. The borrowing firm's position within the industry is also subject to change during the life of the loan. For a longterm fixed rate loan the interest rate would be higher to hedge against future rising market rates than if the rate were allowed to float with the market interest' rate.

The Treasury feels that floating interest rates are unnecessary and unwarranted. They feel that since the guaranty would eliminate the risk of not being repaid, the lender should bear the risk of interest rate changes.

One of the goals of the loan guaranty programs is to develop normal borrower/lender relationships which will continue after the withdrawal of Federal support. In normal borrower/lender relationships; fixed and floating interest rates are options for each loan agreement. If normal relationships are to be established, it seems important for the loan guaranty program management to allow the borrower and lender to negotiate the interest rate terms between them.

- Recommendation - It is recommended that floating interest rates be considered as a viable option in loan guaranties. Permitting floating interest rates would hasten the establishment of normal borrower-lender relationships, would provide for lower initial interest rates, and would encourage the participation of more lenders in the loan guaranty program.

Provisions for the nonwithdrawal of guaranty should negate any justification for any significant increase in the interest rate attributable to increased risk on the part of the lender. If should be recognized, however, that some additional costs to the lender will accrue because of the added Governmental control requirements. Such additional costs would of course be reflected in the interest charged. It is felt that this point can be satisfactorily addressed during the ERDA examination of the loan guaranty application and, if required, negotiated individually with the prospective lender.

\subsubsection{User Charge}

The user charge is the fee charged by the Government to the lending institution for granting the guaranty. The financial community recommended that a 
fixed rate be established for the user charge since this is the practice to which they are most accustomed. They suggested that a flat rate similar to that outlined in SBA regulations be charged.

- Discussion - The only issue brought up on user charges was that a flat rate for the user charge is not stated in the regulations. Lenders would like a fixed rate so that their liability can be calculated before entering into negotiations with borrowers.

- Recommendation - Although this is a relatively minor point, it is recommended that a fixed rate for user charges be explicitly stated in the regulations. If the recommendation under "Default and Liquidation" (4.4.4) is followed, making nonpayment of user charges a condition of default, the user charge should be paid "up front" at the time each disbursement is made. Since a borrower could conceivably not pay the user charge at a later date, such nonpayment could jeopardize the guaranty. This jeopardy could have negative effects on the secondary market for ERDA guarantied paper. This withholding of the user charge would eliminate the problem of defoult for non-payment of user charge for the first year. After the first year, however, the lender must still collect a user charge annually on the anniversary date.

\subsubsection{Interest Assistance}

A suggestion was made that the interest assistance provisions be expanded to include principal assistance, the reason being that if the borrower is having difficulty making inferest payments, he may have equal difficulty in making principal payments which could result in default. This is predicated on the assumption that if the project is worthwhile enough to grant interest assistance, it will also be worthwhile enough to grant principal assistance to save the project from possible default.

- Discussion - The suggestion that interest assistance be expanded to include principal assistance is especially important in the situation where a financially troubled project is interdependent with one or more other projects in the program. In early stages of project development, the debt service payment contains a larger portion of interest than principal. Thus, interest assistance in the early stages of the project is of material benefit. However, in the later stages of the project, where the debt service poyments have a greater portion of principal than interest; the interest assistance provisions take on less 
importance. Obviously, the borrower may have financial difficulties at any stage in the life of the project. In the early part of the project, problems may arise with fixed asset purchases, cost overrun situations and a myriad of other possibilities. In the later stages of the project, when revenues from the project have not begun and working capital is inadequate to cover operating expenses until initial revenues begin, the borrower would also experience cash flow requirement problems.

- Recommendation - It is recommended that both principal and interest assistance be considered to cover all possible financial problems over the life of the project to insure program control, especially in interdependent situations. It is strongly recommended that existing and proposed loan guaranty regulations and the Public Lows authorizing them be modified and/or amended to allow for principal assistance. To this end, an amendment to the Geothermal Energy Research, Development, and Demonstration Act of 1974, Public Law 93-410, has been passed by the House Science and Technology Committee, which would allow interim payments of principal and interest to avoid defaults on worthwhile projects. A similar amendment to the Electric and Hybrid Vehicle Research, Development, and Demonstration Act of 1976, Public Law 94-413, should be addressed. Any future loan guaranty legislation should also contain such a provision.

\subsubsection{Cost Overruns and Cost Escalations}

Since cost overruns and cost escalations occur so frequently in project financing, expecially in the introductory projects of the type we are addressing, this issue must be taken into account when negotiating original loans. The financial community stated that for nonguarantied loans, they normally establish contingency plans (not necessarily known to the borrower) for additional lending as required for overruns and escalations. They felt that if cost increases associated with guarantied loans occurred they would be placed in a precarious position because any further funds lent would be without guaranty. 
- Discussion - If additional funds to cover cost overruns/cost escalations are not available to the borrower, he may not be able to complete the project to the point where it would generate revenues. As a result, the project would be forced into default. Even though a certain degree of cushioning is allowed through interest assistance (or principal assistance), this may not be sufficient to cover cost overruns or escalations. Unfortunately, the financial community cannot act on its own for guarantied loans as it would under nonguarantied loans. Since the establishment of contingency plans for the lending of any additional money over the guarantied portion would not be covered by the guaranty, then the financial community would be exposed to the risk by itself. Contingency plans for cost overruns can be best effected by a joint effort of the ERDA Staff and the lending institution. Any such contingency plans would have to operate within three constraints: the legal limit on the total of all guaranties; the legal limit on individual loan guaranties; and the specific percent of aggregate net cost permitted by law to be guarantied.

- Recommendation - It is recommended that ERDA take the same approach that a lender would take in a nonguarantied loan. Specifically, ERDA should establish contingency plans for additional financing at the beginning of the loan on a case by case basis. This would be worked out with the lender in the form of a higher commitment to guaranty than the actual loan guaranty request, but not piercing the statutory lending limits when the additional funds are included. This contingency commitment could only be exercised upon approval by the Administrator of ERDA. It would not seem necessary to address this ifem in the regulations, but more properly, it should be addressed in the ERDA loan guaranty procedures.

Possible problems that could be encountered with this approach involve potential borrowers, ERDA program management and actual borrowers. Potential borrowers might be denied the benefit of guaranties if the program limit on total guaranties is reached by reserving funds for guaranties for contingency loans although the guaranties have not actually been made. Program managers might be accused of not utilizing the full amount of guaranties permitted by law while denying further guaranties. Actual borrowers might resent the fact that they did not realize full benefit of the guaranty because a portion of it was being held for cost overrun/escalation possibilities. Another problem could exist for the actual borrower if he encounters cost overruns. Since the maximum amount of any guaranty is limited to a fixed percent of aggregate net project cost, any additional guaranty would necessitate the borrower investing 
more capital to cover the nonguarantied portion of the additional cost. The borrower might not have access to this additional required capital.

It should be noted that the providing of contingency guaranties could severely limit the "working capital" available to the ERDA program manager by tieing up funds in a contingency reserve. Consideration could be given to requesting an amendment of the program laws to allow ERDA to exceed the current loan and/or program limits by some fixed percentage subject to certain pre-established control criteria.

\subsubsection{Default Experience}

In discussing default experience in relation to high-risk, high-technology loans, the financial community did not provide a definitive position. Several possible reasons exist regarding their reluctance to comment on this matter. As individuals, they had limited experience in becoming involved with high-risk, high-technology situations; there were insufficient transactions of this nature to develop default ratios; or the particular institution did have experience, however, they considered the information to be proprietary.

\subsubsection{Probable Program Participation}

Summarizing the general feeling, the financial community accepts the broad concept of ERDA guarantied loans. In fact, they specifically stated that the financial community needed "hands-on" experience in these types of loans if normal borrowerlender relationships are to be developed and if the industries are to continue to grow after the expiration of Federal support. However, with the risks associated with these new, high-technology projects, there is virtually no interest in loans with guaranties of less than 100 percent.

To this point, this report has dealt primarily with potential lending institutions and the loan guaranty regulations which would govern participation in various ERDA 
programs. The following paragraphs address interactions between potential lenders and the ERDA staff under the generic area of program control.

\subsubsection{Decision and Approval Authority}

The financial community expressed concern over the level at which loan guaranty agreement decision and approval authority would be vested.

- Discussion-Among the private sector financial community there is a general lack of confidence that the Government can respond in a timely manner. They are concerned that by utilizing the entire organizational structure and placing final authority at the highest levels, the loan guaranty programs may be encumbered by lengthy and/or unacceptable delays in processing required actions. It would seem reasonable that the financial community could be reassured by delegating loan guaranty decision and approval authority to an office subordinate to the Administrator, as is done elsewhere within ERDA. It appears advisable to delegate decision and approval authority to an appropriate official within the specific program office. There is precedence and authority for such delegation. ERDA Temporary Procurement Regulation 21 assigns approval authority for unsolicited proposals in the $\$ 10,000$ to $\$ 5$ million range to the responsible program official or designated official not below the level of division director. Similarly, ERDA Temporary Procurement Regulation 24 assigns approval authority for noncompetitive procurements in the $\$ 10,000$ to $\$ 10$ million range to the appropriate Assistant Administrator. Admittedly, loan guaranties are not the same as the procurements mentioned above. Where procurement contracts always involve the expenditure of funds, loan guaranty funds are expended only when default occurs. Ideally, no funds would ever be expended under loan guaranties. Realistically, however, it must be assumed that default will occur at a rate up to approximately 20 percent of all guaranties approved.

Based on total funds committed for loan guaranties, multiplied by a possible 20 percent default rate, divided by the number of guaranties awarded (assuming all are for the maximum amount), the resultant dollar amount would allow the delegation of decision and approval authority to the appropriate Assistant Administrator consistent with current ERDA practices. 
- Recommendation - It is imperative to the success of these loan guaranty programs that the lending institutions be reassured of the Government's efficient and timely response capability. In keeping with this need, it is recommended that decision and approval authority for loan guaranty agreements be delegated to the appropriate Assistant Administrator. With the Program background and experience available at this level, such delegation would achieve the best organizational compatability. Additionally, there is precedence for the delegation of the authority as recommended. Various ERDA procurement regulations provide for similar delegation down to the division level. Concurrence on decision and approval actions should follow normal ERDA procédures.

In view of the fact there is no other document which indicates to the public the specific office responsible for approval or disapproval of loan guaranty applications, it is further recommended that a statement of delegation be made part of the regulations:

\subsubsection{Program Control}

The potential lenders were concerned that ERDA would not be able to respond rapidly as individual problem situations arose. They felt that the bureaucratic structure of the Government would impede quick resolution of problems that may develop in individual cases.

- Discussion-Each of the ERDA loan guaranty programs is almost certain to encounter programmatic difficulties. Specifically, situations may arise which require industry knowledge, technical familiarity, and rapid solution of the problem. This observation is based on the following points: loan guoranties are outside of the mainstream of ERDA missions; the programs themselves are new within ERDA; each program has a relatively short life; there exists the strong possibility of interdependent loans (the success or failure of the loan can dffect the outcome of one or more projects); and the programs will not have the benefit of many years to develop smooth running routines as a result of many modifications and amendments to existing statutes. Establishment of a single point of contact to resolve specific technical questions would smooth the operation of each loan guaranty program.

The individual loan guaranty program managers will need the latitude and capability to respond rapidly if they are to enjoy the confidence of the lending community and a reduction in the probability of program failure. 
- Recommendation-Each of the loan guaranty programs is basically technology oriented. Therefore, the individual familiar with his particular program should have authority required to respond quickly to programmatic problems. Technical questions need to be addressed from a total program strategy point of view. Since technical decisions would be primary and financial decisions secondary, an individual familiar with the technical details of his generic area of loan guaranties (i.e., the program manager) should serve as the point of contact with both the borrowers and the financial community. Each program manager must run his own program within his area of expertise. To this end, it is recommended that positive program control be vested in the program managers.

The individual program managers should be given sufficient autonomy to directly interface with members of the financial community, borrowers, and Governmental agencies. This authority should be made clear in the regulations. In the Geothermal Program, within its loan guaranty regulations, authority has been specifically assigned to the program manager. For the Electric and Hybrid Vehicle and subsequent ERDA Programs, an additional recommendation is made to include a designation of the primary ERDA point of contact for the public. This would preclude unnecessary contact with other ERDA officials who may not be completely familiar with the specific programs. It is felt that such actions would be in keeping with recent Presidential statements concerning identification of the individual responsible for program management.

\subsection{Summary of Principal Points and Recommendations}

Several significant and important aspects of ERDA loan guaranty programs have been discussed throughout this report. Those considered as capable of impacting ERDA programs most critically are summarized below.*

\section{Full Faith and Credit}

- ERDA loan guaranty regulations and the Public Laws authorizing them should be modified and/or amended to include a definitive statement of "full faith and credit."

\section{Loan Guaranty Withdrawal}

- $\quad$ The Geothermal Loan Guaranty Regulation should be amended to provide that "in any event, excluding fraud and misrepresentation, the lender shall be reimbursed for unpaid principal and accrued interest," for amounts previously disbursed by mutual consent of the lender and ERDA.

* Specific breakdowns by program are included in Appendix $E$. 


\section{Payment Upon Default}

- A specific fund should be established to support the Electric and Hybrid Vehicle loan guaranties and any future similar programs to assure potential lenders that funds will be available to make payment upon default.

- ERDA should seek revolving appropriations for funds to cover at least 20 percent of anticipated outstanding loan guaranties.

- ERDA should be empowered with authority to borrow, from the Treasury, funds necessary to discharge the Government obligation upon default in a timely manner.

- Interest rates for the period between date of default and date of payment should continue at the same rate as was in effect for the loan.

\section{Default and Liquidation}

- If provisions for technical default exist on the loan agreement, ERDA should be informed regularly of the status of the technical default indicators.

- Some flexibility should be allowed the lender in postponing the calling of default. This flexibility should be provided for in the regulations.

- ERDA loan guaranty regulations should be changed to define default as "nonpayment of principal, interest, or user charge (if the user charge is passed on to the borrower)."

\section{Loan Servicing}

- The current Geothermal Regulation and the regulations for future loan guaranty programs should be identical with the Electric and Hybrid Vehicle Regulation with respect to the area of guaranty withdrawal.

\section{Secondary Market Considerations}

- The possibility of divisibility should be considered by the ERDA Office of the General Counsel to determine the most reasonable approach. All sale and re-sale procedures of guarantied loans should be documented and standardized.

\section{Interest Rates}

Floating interest rates should be considered as a viable option in loan guaranties. 
User Charge

A fixed rate for user charges should be explicitly stated in the regulations.

- The user charge should be paid at the time each disbursement is made.

Interest Assistance

- Existing and proposed loan guaranty regulations and the Public Laws authorizing them should be modified and/or amended to allow for interest and principal assistance.

\section{Cost Overruns and Cost Escalations}

- ERDA should establish contingency plans for additional financing for cost overrun/escalations at the beginning of each loan on a case by case basis.

- Consideration should be given to requesting amendments to program laws to allow ERDA to exceed the current loan and/or program limits by some fixed percentage to allow contingency guaranties for project cost overrun/escalations.

Decision and Approval Authority

- Decision and approval authority, related to loan guaranties and subsequent related actions, should be delegated to the office of the appropriate Assistant Administrator. Such designation of authority should be stated in the regulations.

\section{Program Control}

- Positive program control should be vested in the program managers.

- Individual program managers should be given sufficient autonomy to directly interface with members of the financial community, borrowers and Governmental agencies.

- Designation of the program manager as a point of contact should be included in the regulations.

\subsection{General Conclusions}

In the opinion of the study team, the financial community representatives generally accept the broad concepts underlying the ERDA loan guaranty programs. 
However, due to the risks associated with these new high-technology programs, virtually no interest was expressed for granting loans which would be less than 100 percent guarantied. It was expressly stated that before the marketplace could establish a normal borrower-lender relationship, experience had to be gained by the lending community under the full protection of Federal loan guaranties.

In general, most participants expressed their pleasure in having been offered the opportunity to openly discuss their concerns during the early program stages. As was pointed out by a number of individuals, these programs will not have the luxury of time for continued refinement of procedures and regulations as have been the case with the high-volume, long-life programs of the SBA, FHA, FmHA, etc.

Again, in the opinion of the study team, it is felt that considerable interest in the ERDA loan guaranty programs has been generated, partly because of the discussions which took place. This is evidenced by the numerous follow-up contacts the team has had subsequent to the meetings. It is recommended that these channels remain open and used to maximum advantage for existing and future loan guaranty programs. 

APPENDIX A

\section{Discussion Participants}

\section{Boston}

Donald A. Blake, Vice President

New England Merchants National Bank

Prudential Center

Boston, Massachusetts

617-742-4000

Patrick F. Connolly, Vice President

Shawmut Bank of Boston, N. A.

One Federal Street

Boston, Massachusetts 02110

617-292-2927
Paul F. Hogan, Loan Officer

The First National Bank of Boston

100 Federal Street

Boston, Massachusetts

617-434-3846

William Mck. Rust, Vice President

State Street Bank and Trust Company

225 Franklin Street

Boston, Massachusetts 02101

617-786-3677

\section{New York}

Harry Baechtdold

Marine Midland Bank

140 Broadway

New York, New York 10015

212-797-4000

Gabor J. Csordas

Bank of New York

48 Wall Street

New York, New York 10015

212-530-1748

Thomas J. Edelman, Assistant Vice President

Kuhn, Loeb \& Company, Inc.

40 Wall Street

New York, New York 10005

212-797-4654

John D. Hiensch, National Division

National Bank of North America

44 Wall Street

New York, New York 10005

212-623-4000

Daniel F. D. McKinley, Vice President

Bankers Trust Company

280 Park Avenue

New York, New York 10022

212-692-7156

Thomas H. Suitt, Jr.

Manufacturers Hanover Trust

350 Park Avenue

New York, New York 10022

212-350-4819
Warren P. Chatmon, Executive Vice President Daniels \& Bell, Inc.

20 Exchange Place

New York, New York

212-422-1700

Johan de Voogd, Account Officer

Citibank, N. A.

399 Park Avenue

New York, New York 10022

2|2-559-7||12

David L. Eyles, Senior Vice President

Chemical Bank

20 Pine Street

New York, New York 10005

212-770-1712

Kevin B. McCarthy

Lehman Government Securities, Inc.

One William Street

New York, New York 10004

212-269-3700

G. R. Ries

Bache, Halsey, Stuart

100 Huld Street

New York, New York 10038

2|2-79|-3626

Sheldon Sixfin, Technical Director, Environmental Systems

The Chase Manhattan Bank, N. A.

One Chase Manhattan Plaza

New York, New York 10015

212-522-6549 


\section{New York (Continued)}

James J. Wallace, Jr., Assistant Vice President Irving Trust Company

One Wall Street

New York, New York 10015

212-487-6039

Gordon R. Watson, Vice President

Merrill, Lynch, Hubbard, Inc.

One Liberty Plaza

165 Broadway

New York, New York 10006

212-766-6157
Mary E. Watkins

Morgan Guaranty Trust Company

23 Wall Street

New York, New York 10015

212-483-1738

Larry C. Williams

The Robinson-Humphrey Company, Inc.

Two Peachtree Street, N. W.

Atlanta, Georgia 30303

404-581-7131

Richard S. Williams, Vice President

E. F. Hutton \& Company, Inc.

One Battery Park Plaza

New York, New York 10004

\section{Atlanto}

Franklin L. Burke, Senior Vice President The Fulton National Bank of Atlanta P. O. Box 4387

Atlanta, Georgia 30302

404-577-3500

William H. Leslie, Group Vice President Trust Company Bank

P. O. Box 4418

Atlanta, Georgia 30302

404-588-7594

Clif White, Vice President

W. Dobbs \& Company

250 Piedmont Avenue, N. E.

Atlanta, Georgia 30308

404-659-3323

\section{Chicago}

Thomas F. Duffy, Vice President

The Northern Trust Company

50 South LaSalle Street

Chicago, lllinois 60690

312-630-6000
L. O. Farris, Jr., Vice President

The Fulton National Bank of Atlanta

P. 0. Box 4837

Atlanta, Georgia 30302

404-577-3500

Jay M. McDonald, Vice President

The Citizens and Southern National Bank 99 Annex

Atlanta, Georgia 30399

404-581-3095

William L. Wingate, Jr. Vice President

The First National Bank of Atlanta

Atlanta, Georgia 30303

404-588-5245

Thomas F. Mullaney, Jr., Vice President

First National Bank of Chicago

One First National Plaza

Chicago, Illinois 60670

312-732-6140

Dennis L. Winget, Commercial Banking Officer

Continental Illinois National Bank \& Trust

Company of Chicago

231 South LaSalle Street

Chicago, Illinois 60693

312-828-8143 
Houston

Alton M. Bathrick, Vice President

Hibbard, O'Connor \& Weeks, Inc.

1300 Main Street

Houston, Texas 77002

$7|3-65|-1|1|$

W. W. Cumberland, Jr., Assistant Vice President

Bank of the Southwest

910 Travis

Houston, Texas 77001

$7 \mid 3-751-6100$

Fred M. Haston, Jr., Vice President

Capital National Bank

1300 Main Street

Houston, Texas 77001

$7|3-65|-1100$
R. David Cullum, Assistant Vice President First City National Bank

P. O. Box 2557

Houston, Texas 77001

7|3-658-6036

Robert G. Florance, Vice President Jessup \& Lamont, Inc.

One Greenway Plaza East

Houston, Texas 77046

713-960-0370

G. Al Perrine, Vice President

Business Finance Center of America, Inc.

1853 Lexington

Houston, Texas 77098

7|3-529-495|

James B. Trimble, Assistant Vice President

Bank of the Southwest

910 Travis

Houston, Texas 77001

7|3-75|-6100

\section{San Francisco}

Glenn W. Berry, Jr., Vice President

Crocker National Bank

79 New Montgomery Street

San Francisco, California 94105

415-983-6462

Walt Laffranchini, Assistant Vice President

California First Bank

370 California Street

San Francisco, California 94104

415-445-0235
William E. Cannady, Vice President

Crocker National Bank

One Montgomery Street

San Francisco, California 99104

415-983-3840

Frank Sperling, Vice President

Bark of America

Bank of America Center

San Francisco, California 94137

415-622-4563 



\section{APPENDIX B}

\section{Points of Contact}

Federal Home Loan Bank Board Mrs. Elaine Miller

U. S. League of Savings Associations

Mr. Barry Tate

National Savings and Loan League

Mr. Richard Knight

Federal Deposit Insurance Corporation

Mr. Robert Egger

National Association of Mutual Savings Banks

Mr. Jack Rubinson

National Credit Union Administration

Mr. Wilmer Theart

National Association of Federal Credit Unions

Mr. James Barr

Credit Union National Association

Mr. Harry Thomas

Department of Labor

Pension and Benefit Welfare

Mr. Owen McArdle

International Brotherhood of Teamsters

Research Group

Securities and Exchange Commission

Division of Investment Management

Mr. George Washburn

Securities and Exchange Commission

Division of Corporate Finance

Mr. John Mooney

Securities and Exchange Commission

Division of Economic Research

Mr. Paul Livingston

Investment Company Institute

General Counsel

National Association of Real Estate Investment Trusts

Federal Reserve System

Division of Research and Statistics

Mr. Paul Boltz 
Comptroller of the Currency

Bank Organization and Structure

Mr. Hugh Eggleton

Federal Deposit Insurance Company

Bank Division

Mr. John McCarthy

American Bankers Association

Mr. Edward Hoffman

Independent Bankers Association of America

Mr. Howard Bell

Securities and Exchange Commission

Division of Market Regulation

Mr. Jeffrey Steel

The Securities Industry Association

National Association of Securities Dealers

Public Securities Association

Mr. Robert Kline

Government Guaranteed Loan Association

Mr. William Moore

American Council of Life Insurance

Dr. Kenneth Wright

State of Pennsylvania

Department of Insurance

Mr. K. G. Somers 


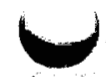

APPENDIX C

DEMAND DEPOSITS

C-1 
APPENDIX C

Source : Board of Governors of the Federal Reserve

Demand Deposits (\$000) March 1977

\begin{tabular}{|c|c|}
\hline New England & \\
\hline $\begin{array}{l}\text { Maine: } \\
\text { Bangor } \\
\text { Lewiston-Auburn } \\
\text { Portland-South Portland }\end{array}$ & $\begin{array}{r}63,249 \\
35,713 \\
187,188\end{array}$ \\
\hline $\begin{array}{l}\text { New Hampshire: } \\
\text { Concord } \\
\text { Manchester }\end{array}$ & $\begin{array}{l}42,867 \\
87,062\end{array}$ \\
\hline $\begin{array}{l}\text { Vermont: } \\
\quad \text { Burlington }\end{array}$ & 125,903 \\
\hline $\begin{array}{l}\text { Massachusetts: } \\
\text { Boston } \\
\text { Brockton } \\
\text { Fall River } \\
\text { Lawrence-Haverhill } \\
\text { Lowell } \\
\text { New Bedford } \\
\text { Pittsfield } \\
\text { Springfield-Chicopee-Holyoke } \\
\text { Worcester }\end{array}$ & $\begin{array}{r}3,781,155 \\
85,295 \\
73,733 \\
196,962 \\
81,190 \\
67,531 \\
68,810 \\
306,168 \\
284,650\end{array}$ \\
\hline $\begin{array}{l}\text { Connecticut: } \\
\text { Hartford } \\
\text { New Haven } \\
\text { Norwich-Groton-New London } \\
\text { Waterbury } \\
\text { Bridgeport } \\
\text { Stamford }\end{array}$ & $\begin{array}{l}887,960 \\
296,299 \\
104,981 \\
172,258 \\
319,328 \\
316,254\end{array}$ \\
\hline $\begin{array}{l}\text { Rhode Island: } \\
\quad \text { Providence-Warwick-Pawtucket }\end{array}$ & 734,580 \\
\hline New England Total: & $8,319,1.36$ \\
\hline
\end{tabular}


Mid Atlantic

New York:

Binghamton

Buffalo

New York

Rochester

Syracuse

Utica-Rome

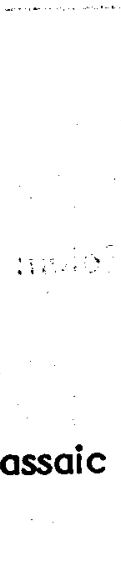

New Jersey:

Jersey City

Newark

Patterson-Clifton-Passaic

Atlantic City

Trenton

192,643

946,309

$33,250,477$

$783,7.17$

537,590

190,699

439,044

$2,047,264$

$1,516,959$

250,286

569,894

Pennsylvania:

Altoona

Harrisburg !

Johnstown

Lancaster

Lebanon

Allentown-Easton-Bethlehem

Philadelphia

Reading

Scranton

Wilkes-Barre-Hazelton

Williamsport

York

Erie

Pittsburgh

Delaware:

Wilmington

Maryland:

Baltimore

83,142

443,132

153,941

488,055

$45,7.19$

381,804

$5,549,788$

352,206

182,636

315,613

94,648

257,716

259,001

$3,130,048$

inia:

Lynchburg

Newport News-Hampton

Norfolk-Virginia Beach-Portsmouth

Richmond

Roanoke

\section{West Virginia:}

Charleston

Huntington-Ashland, Kentucky

Wheeling

708,938

$2,009,919$

135,316

219,821

634,760

988,574

246,510

24,510

376,845

276,970

190,817

District of Cólumbia:

Washington

$3,763,898$

Mid Atlantic Total:

$62,014,699$ 


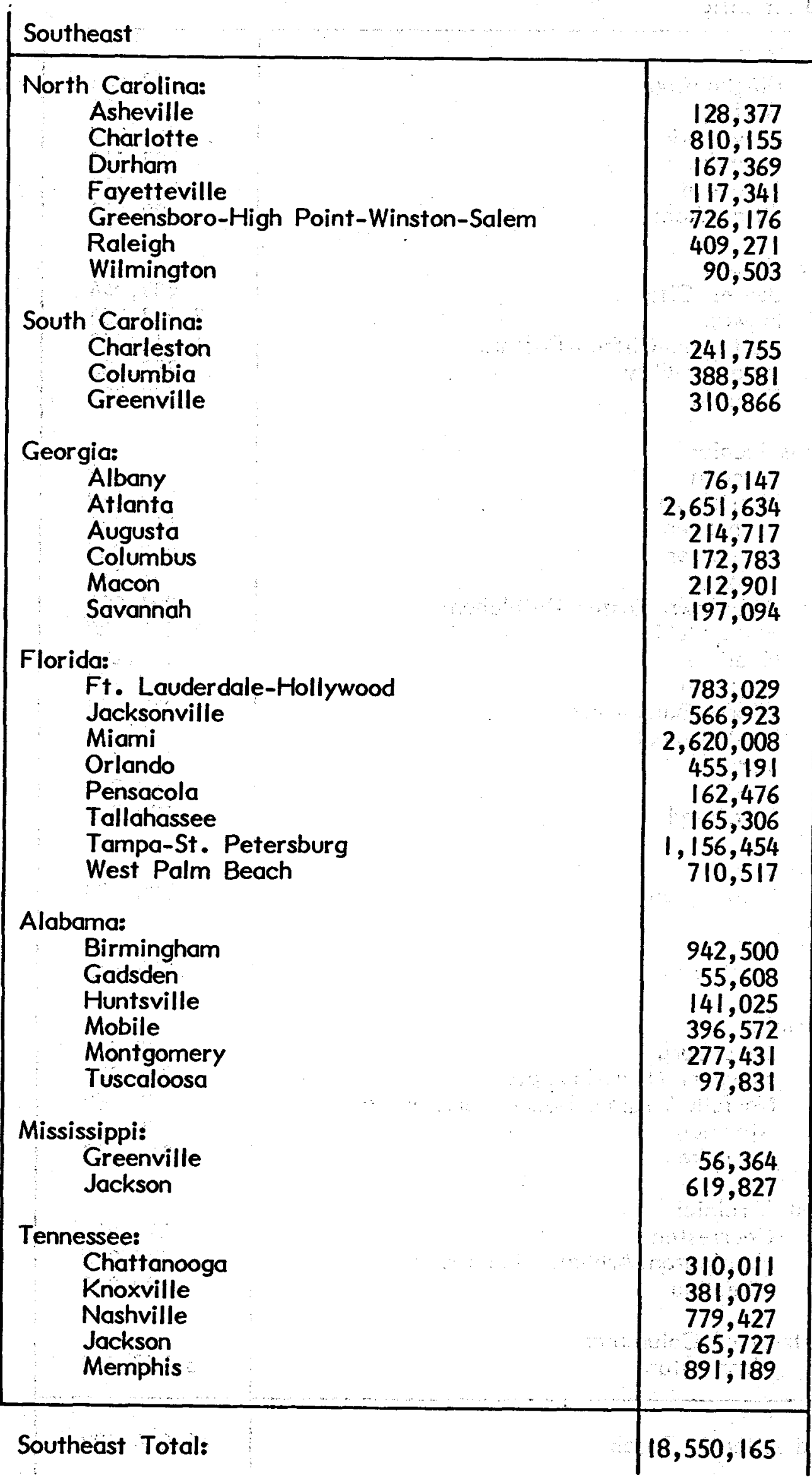


North Central

Michigan:

Ann Arbor

Bay City

Detroit

Flint

Grand Rapids

Jackson

Kalamazoo

Lansing-East Lansing

Muskegon-Muskegon Heights

Saginaw

216,236

65,374

$4,555,144$

258,866

515,701

132,475

204,225

293,729

82,551

177,907

Ohio:

Akron

Canton

Cincinnati

Cleveland

Columbus

Dayton

Hamilton-Middleton

Lima

Lorain-Elyria

Mansfield

Springfield

Steubenville-Weirton, West Virginia

Toledo

Youngstown-Warren

612,663

355,244

$1,419,151$

$2,496,358$

$1,070,246$

804,765

193,901

177,463

175,755

$|16,8| \mid$

89,821

121,856

641,962

376,044

Indiana:

Fort Wayne

Gary-Hammond-East Chicago

Indianapolis

Lafayette-West Lafayette

Muncie

South Bend

Terre Haute

Evansville

343,318

539,765

$1,305,299$

122,628

105,246

261,767

172,520

290,990

Illinois:

Bloomington-Normal

Champaign-Urbana

Chicago

Davenport-Rock Island-Moline

Decatur

Peoria

Rockford

Springfield

Quincy

159,736

198,743

$13,396,659$

395,563

156,337

402,554

260,358

261,954

76,709

Kentucky:

Lexington

Louisville

Owensboro

Paducah

283,007

$1.022,067$

104,695

75,871 


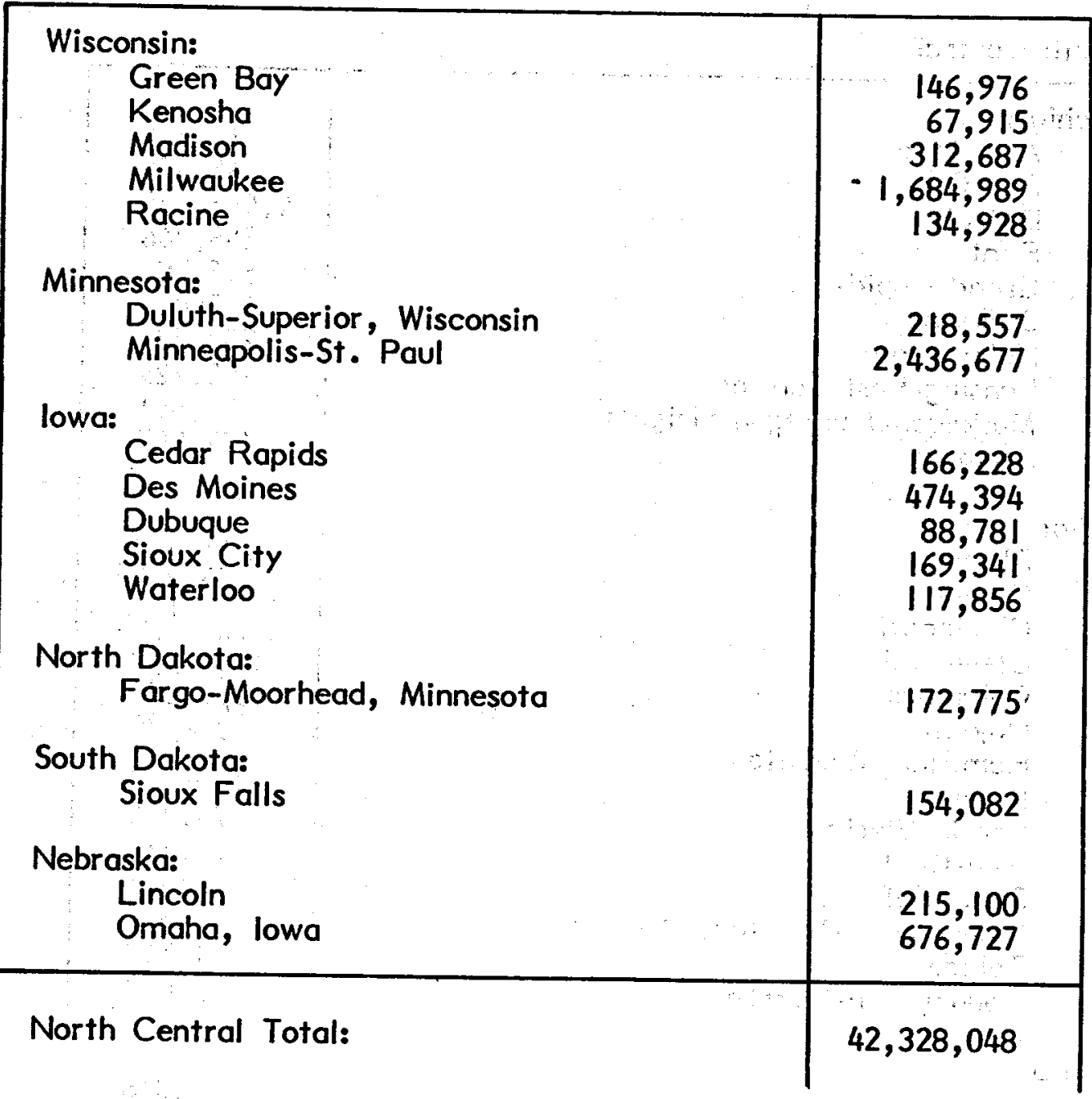


South Central

Texas:

Abilene

Amarillo

Austin

Beaumont-Port Arthur-Orange

Brownsville-Harlingen-San Benito

Corpus Christi

Corsicana

Dallas

El Paso

Fort Worth

Galveston-Texas City

Houston

Laredo

Lubbock

McAllen-Pharr-Edinburg

Midland

Odessa

San Angelo

San Antonio

Tyler

Waco

Wichita Falls

178,544

300,401

627,596

399,772

158,521

381,045

46,297

$3,799,008$

395,351

$1,176,438$

181,463

4,902,990

101,355

283,357

210,865

268,332

184,962

125,642

$1,088,627$

187,435

181,946

203,253

Oklahoma:

Lawton

Oklahoma City

Tulsa

90,437

985,734

929,743

Arkansas:

El Dorado

Fort Smith

Helena

Little Rock-North Little Rock

Pine Bluff

Texarkana, Texas

57,600

200,852

19,434

489,124

99,070

109,377

Louisiana:

Baton Rouge

Lafayette

Lake Charles

New Orleans

Monroe

Shreveport

439,239

189,916

176,723

$1,537,921$

154,224

423,583

Kansas:

Topeka

Wichita

191,814

520,265 


\begin{tabular}{|c|r|}
\hline Missouri: & \\
Cape Girardeau & 55,601 \\
Hannibal & 24,076 \\
St. Lovis & $2,775,378$ \\
Kansas City, Kansas & $1,759,514$ \\
St. Joseph & 106,176 \\
Sedalia & 36,528 \\
Springfield & 199,256 \\
\hline South Central Total: & \\
\hline
\end{tabular}


West

Montana:

Billings

Great Falls

141,483

109,384

Colorado:

Colorado Springs

Denver

234,222

Pueblo

$1,883,209$

85,997

New Mexico:

Albuquerque

Roswell

430,640

60,679

Idaho:

Boise City

220,251

Utah:

Ogden

Salt Lake City

121,766

756,354

Nevada:

Las Vegas

Reno

417,314

287,072

Arizona:

Phoenix

Tucson

$1,402,038$

408,618

Washington:

Seattle-Everett

Spokane

Tacoma

$1,603,737$

418,140

311,551

Oregon:

Eugene-Springfield

209,700

Portland

$1,389,774$

California:

Anaheim-Santa Ana-Garden Grove

$1,959,602$

354,540

Bakersfield

508,037

Fresno

Los Angeles-Long Beach

Oxnard-Simi Valley-Ventura

Riverside-San Bernardino-Ontario

$11,753,065 *$

316,332

955,870

San Diego

San Francisco-Oakland

San Jose

Santa Barbara-Santa Maria-Lompoc

Stockton

$1,521,505$

$6,043,223$

$1,276,310$

300,784

284,430

West Total:

$35,765,627$

*Although Los Angeles had the largest amount of Demand Deposits, further research showed that main offices of the largest volume banks were located in San Francisco. 

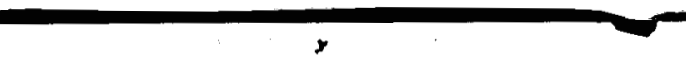

APPENDIX D

GROSS FUNDS SUPPLIED

BY TYPE OF LENDER

D-1 


\section{GROSS FUNDS SUPPLIED, BY TYPE OF LENDER}

GEASONALLY aOJUSTEO ANMUAL RATEB. haLF-VEAR tOTALS
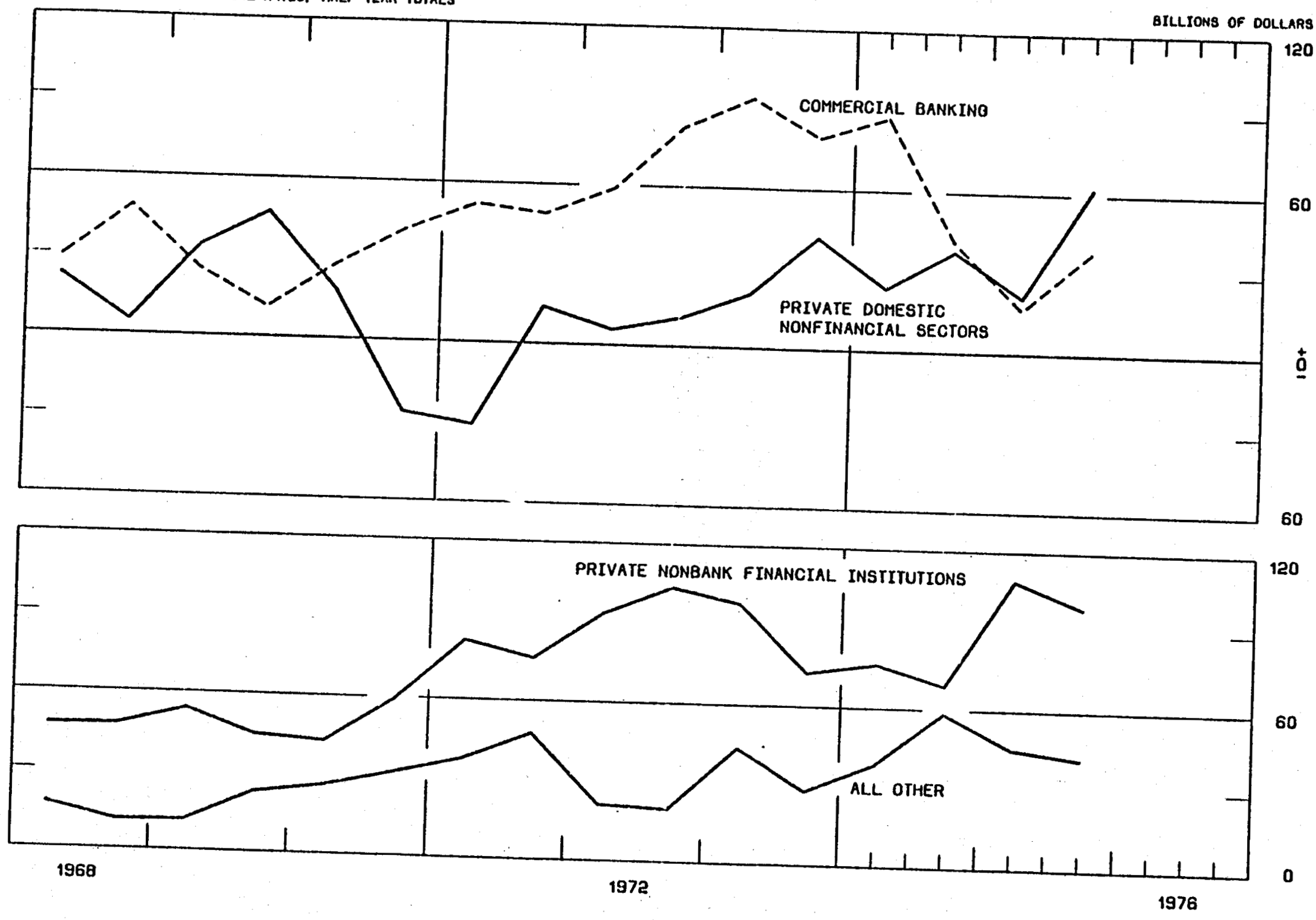

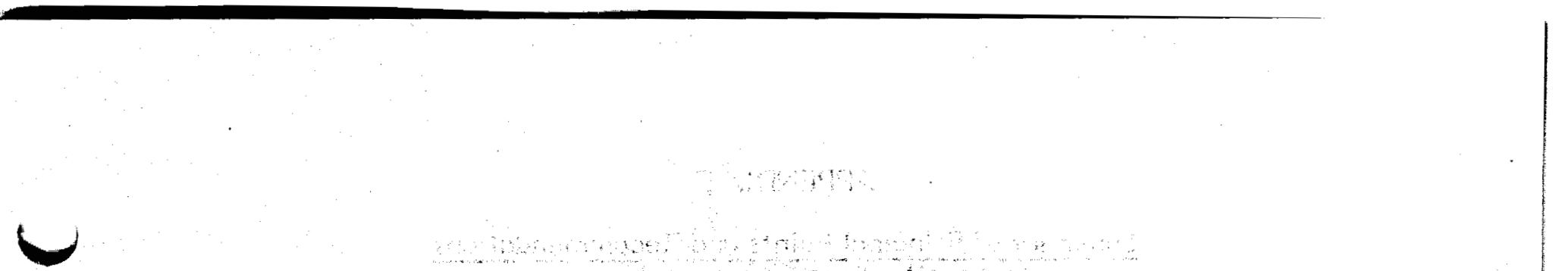

\section{APPENDIXE \\ SUMMARY OF PRINCIPAL POINTS AND RECOMMENDATIONS BY SPECIFIC LOAN GUARANTY PROGRAM}




\section{APPENDIX E \\ Summary of Principal Points and Recommendations \\ by Specific Loan Guaranty Program}

\section{Geothermal Loan Guaranty Program}

Full Faith and Credit

- The Geothermal Loan Guaranty Regulation and the Geothermal Energy Research, Development, and Demonstration Act of 1974 (Public Law 93$410)$ should be modified and/or amended to include a definitize statement of "full faith and credit."

Loan Guaranty Withdrawal

- The Geothermal Loan Guaranty Regulation should be amended to provide that "in any event, excluding fraud and misrepresentation, the lender shall be reimbursed for unpaid principal and accrued interest," for amounts previously disbursed by mutual consent of the lender and ERDA.

\section{Payment Upon Default}

- ERDA should seek revolving appropriations for funds to cover at least 20 percent of anticipated outstanding Geothermal loan guaranties.

- ERDA should be empowered with authority to borrow from the Treasury funds necessary to discharge the Government obligation upon default in a timely manner.

- Interest rates for the period between date of default and date of payment should continue ot the same rate as was in effect for the loan.

\section{Default and Liquidation}

- If provisions for technical default exist on the loan agreement, ERDA should be informed regularly of the status of the technical default indicators.

- Some flexibility should be allowed the lender in postponing the calling of default. This flexibility should be provided for in the Geothermal Loan Guaranty Regulation.

- The Geothermal Loan Guaranty Regulation should be changed to define default as "nonpayment of principal, interest, or user charge (if the user charge is passed on to the borrower."

\section{Loan Servicing}

- The current Geothermal Regulation should be identical with the Electric and Hybrid Vehicle Regulation with respect to the area of guaranty withdrawal. 
Secondary Market Considerations

- The possibility of divisibility should be considered by the ERDA Office of the General Counsel to determine the most reasonable approach. All sale and re-sale procedures of guarantied loans should be documented and standardized.

Interest Rates

Floating interest rates should be considered as a viable option in loan guaranties.

User Charge

A fixed rate for user charges should be explicitly stated in the Geothermal Loan Guaranty Regulation.

- The user charge should be paid at the time each disbursement is made.

Interest Assistance

- The Geothermal Loan Guaranty Regulation and the Geothermal Energy Research, Development, and DemonstrationAct of 1974 (Public Law 93410) should be modified and/or amended to allow for interest and principal assistance.

Cost Overruns and Cost Escalations

- ERDA should establish contingency plans for additional financing for cost overrun/escalations at the beginning of each loan on a case by case basis.

- Consideration should be given to requesting amendments to the Geothermal Energy Research, Development and Demonstration Act of 1974 (Public Law 93-410), to allow ERDA to exceed the current loan and/or program limits by some fixed percentage to allow contingency guaranties for project cost overrun/escalations.

\section{Decision and Approval Authority}

- Decision and approval authority, related to loan guaranties and subsequent related actions, should be delegated to the Office of the Assistant Administrator for Solar, Geothermal, and Advanced Energy Systems. Such designation of authority should be stated in the Geothermal Loan Guaranty Regulation.

\section{Program Control}

- The Geothermal Loan Guaranty Program Manager should be given sufficient autonomy to directly interface with members of the financial community, borrowers and Governmental agencies. 
Electric and Hybrid Vehicle Loan Guaranty Program

\section{Full Faith and Credit}

- The Electric and Hybrid Vehicle Loan Guaranty Regulation and the Electric and Hybrid Research, Development, and Demonstration Act of 1976 (Public Law 94-413) should be modified and/or amended to include a definitive statement of "full faith and credit."

\section{Payment Upon Default}

- A specific fund should be established to support the Electric and Hybrid Vehicle loan guaranties to assure potential lenders that funds will be available to make payment upon default.

- ERDA should seek revolving appropriations for funds to cover at least 20 percent of anticipated outstanding loan guaranties.

- ERDA should be empowered with authority to borrow, from the Treasury, funds necessary to discharge the Government obligation upon default in a timely manner.

- Interest rates for the period between date of default and date of payment should continue at the same rate as was in effect for the loan.

\section{Default and Liquidation}

- If provisions for technical default exist on the loan agreement, ERDA should be informed regularly of the status of the technical default indicators.

- Some flexibility should be allowed the lender in postponing the calling of default. This flexibility should be provided for in the Electric and Hybrid Vehicle Loan Guaranty Regulation.

- The Electric and Hybrid Vehicle Loan Guaranty regulation should be changed to define default as "nonpayment of principal, interest, or user charge (if the user charge is passed on to the borrower)."

\section{Secondary Market Considerations}

- The possibility of divisibility should be considered by the ERDA Office of the General Counsel to determine the most reasonable approach. All sale and re-sale procedures of guarantied loans should be documented and standardized. 
Interest Rates

- Floating interest rates should be considered as a viable option in loan guaranties.

\section{User Charge}

- A fixed rate for user charges should be explicity stated in the Electric and Hybrid Vehicle Loan Guaranty Regulation.

- The user charge should be paid at the time each disbursement is made.

Interest Assistance

- The Electric and Hybrid Vehicle Loan Guaranty Regulation and the Electric and Hybrid Vehicle Research, Development, and Demonstration Act of 1976 (Public Law 94-413) should be modified and/or amended to allow for interest and principal assistance.

\section{Cost Overruns and Cost Escalations}

- ERDA should establish contingency plans for additional financing for cost overrun/escalations at the beginning of each loan on a case by case basis.

- Consideration should be given to requesting amendments to the Electric and Hybrid Vehicle Research, Development, and Demonstration Act of 1976 (Public Law 94-413) to allow ERDA to exceed the current loan and/or program limits by some fixed percentage to allow contingency guaranties for project cost overrun/escalations.

\section{Decision and Approval Authority}

- Decision and approval authority, related to loan guaranties and subsequent related actions, should be delegated to the Office of the Assistant Administrator for Conservation. Such designation of authority should be stated in the Electric and Hybrid Vehicle Loan Guaranty Regulation.

\section{Program Control}

- Positive program control should be vested in the Electric and Hybrid Vehicle Loan Guaranty Program Manager.

- The Electric and Hybrid Vehicle Loan Guaranty Program Manager should be given sufficient autonomy to directly interface with members of the financial community, borrowers and Governmental agencies.

- Designation of the Electric and Hybrid Vehicle Loan Guaranty Program Manager as a point of contact should be included in the Electric and Hybrid Vehicle Loan Guaranty Regulation. 
$\forall$

\section{APPENDIX F \\ BIBLIOGRAPHY}




\section{BIBLIOGRAPHY}

Baughn, William H. and Walker, Charles E., ed., The Bankers Handbook. Homewood Illinois: Dow Jones-Irwin, 1966.

Culbertson, John M., Money and Banking. New York: McGraw Hill, 1972.

Dawson, Townes Loring and Mounce, Earl Winifield. Business Law Text and Cases. Lexington, Massachusetts: D. C. Heath, 1968.

Dorfman, Robert. The Price System. Englewood Cliffs, New Jersey: Prentice-Hall, 1964.

Duesenberry, James S. Money and Credit: Impact and Control. Englewood Cliffs, New Jersey: Prentice-Hall, 1964.

Eckstein, Otto. Public Finance. Englewood Cliffs, New Jersey: Prentice-Hall, 1964.

Francis, Jack Clark. Investments: Analysis and Management. New York: McGraw Hill, 1972.

Havrilesky, Thomas M. and Boorman, John T. Current Perspectives in Banking. Arlington Heights, Illinois: AHM Publishing, 1976.

Kohler, Eric L. A Dictionary for Accountants. Englewood Cliffs, New Jersey: PrenticeHall, 1970.

Nevitt, Peter K. Project Financing. Chicago: AMR International, 1975.

Reed, Edward W.; Cotter, Richard V.; Gill, Edward K, and Smith, Richard K. Commercial Banking. Englewood Cliffs, New Jersey: Prentice-Hall, 1976.

Ritter, Lawrence S. and Silber, William L. Money. New York: Basic Books, 1973. Basic Books, 1974.

- Principles of Money, Banking, and Financial Markets. New York:

Robinson, Roland 1. and Wrightsman, Dwayne. Financial Markets: The Accumulation and Allocation of Wealth. New York: McGraw Hill, 1974.

Samuelson, Paul A. Economics. New York: McGraw Hill, 1973. 